\title{
The Endocannabinoid 2-Arachidonoylglycerol Negatively Regulates Habituation by Suppressing Excitatory Recurrent Network Activity and Reducing Long-Term Potentiation in the Dentate Gyrus
}

\author{
Yuki Sugaya, ${ }^{1}$ Barbara Cagniard, ${ }^{1}$ Maya Yamazaki, ${ }^{2}$ Kenji Sakimura, ${ }^{2}$ and Masanobu Kano ${ }^{1}$ \\ ${ }^{1}$ Department of Neurophysiology, Graduate School of Medicine, The University of Tokyo, Tokyo 113-0033, Japan and ${ }^{2}$ Department of Cellular \\ Neurobiology, Brain Research Institute, Niigata University, Niigata 951-8585, Japan
}

\begin{abstract}
Endocannabinoids are known to mediate retrograde suppression of synaptic transmission, modulate synaptic plasticity, and influence learning and memory. The 2-arachidonoylglycerol (2-AG) produced by diacylglycerol lipase $\alpha$ (DGL $\alpha$ ) is regarded as the major endocannabinoid that causes retrograde synaptic suppression. To determine how 2-AG signaling influences learning and memory, we subjected DGL $\alpha$ knock-out mice to two learning tasks. We tested the mice using habituation and odor-guided transverse patterning tasks that are known to involve the dentate gyrus and the CA1, respectively, of the hippocampus. We found that DGL $\alpha$ knock-out mice showed significantly faster habituation to an odor and a new environment than wild-type littermates with normal performance in the transverse patterning task. In freely moving animals, long-term potentiation (LTP) induced by theta burst stimulation was significantly larger at perforant path-granule cell synapses in the dentate gyrus of DGL $\alpha$ knock-out mice. Importantly, prior induction of synaptic potentiation at this synapse caused a significant retardation of habituation in DGL $\alpha$ knock-out but not in wild-type littermates. The excitability of granule cells became higher in DGL $\alpha$ knock-out mice after they generated action potentials. Since no differences were found in intrinsic membrane properties and responses to odor stimuli in granule cells, the elevated excitability is considered to result from enhanced activity of an excitatory recurrent network composed of granule cells and mossy cells. These results suggest that retrograde 2-AG signaling negatively regulates habituation by suppressing excitatory recurrent network activity and reducing LTP in the dentate gyrus.
\end{abstract}

\section{Introduction}

Endocannabinoids are known to modulate synaptic transmission in various regions of the brain (Kano et al., 2009; Castillo et al., 2012; Ohno-Shosaku et al., 2012). They are released from postsynaptic neurons in an activity-dependent manner, travel backward to presynaptic terminals, activate cannabinoid $\mathrm{CB}_{1}$ receptors, and cause short-term or long-term suppression of transmitter release. As for brain functions, many studies have shown that the endocannabinoid system plays an important role in learning and memory in several brain areas including the hippocampus (Abush and Akirav, 2010), amygdala (Marsicano et al., 2002), and cerebellum (Kishimoto and Kano, 2006). It is not

Received July 3, 2012; revised Dec. 26, 2012; accepted Jan. 3, 2013.

Author contributions: Y.S., B.C., and M.K. designed research; Y.S. and B.C. performed research; M.Y. and K.S. contributed unpublished reagents/analytic tools; Y.S. and B.C. analyzed data; Y.S., B.C., and M.K. wrote the paper.

This work has been supported by Grants-in-Aid for Scientific Research (21300118 to K.S. and 21220006 to M.K.), the Strategic Research Program for Brain Sciences (Development of Biomarker Candidates for Social Behavior), and the Global COE Program (Integrative Life Science Based on the Study of Biosignaling Mechanisms) from MEXT, Japan. We thank E. Maru, S. Jinde, and K. Kasai for technical assistance and for J.M. Good and M. Mahoney for critically reading this manuscript.

The authors declare no competing financial interests.

Correspondence should be addressed to Masanobu Kano, Department of Neurophysiology, Graduate School of Medicine, the University of Tokyo, 7-3-1 Hongo, Tokyo 113-0033, Japan. E-mail: mkano-tky@m.u-tokyo.ac.jp.

DOI:10.1523/JNEUROSCI.3141-12.2013

Copyright $\odot 2013$ the authors $\quad 0270-6474 / 13 / 333588-14 \$ 15.00 / 0$ clear, however, how endocannabinoid signaling influences learning and memory. For example, blockade of cannabinoid signaling impairs memory extinction without affecting its acquisition (Marsicano et al., 2002; Varvel and Lichtman, 2002), whereas the same manipulation could enhance the acquisition of memory in some learning tasks (Degroot et al., 2005; Robinson et al., 2008).

Habituation is defined as the waning of a response generated by repeated exposure to a novel stimulus. It is recognized as a primitive form of nonassociative learning ubiquitously observed among animals, and as the most elementary form of behavioral plasticity (Leussis and Bolivar, 2006). The hippocampus is considered to be involved in this primitive form of behavioral plasticity. Hippocampectomized rats showed impaired habituation to objects in an open field (Wright et al., 2004). Exposure to a novel space increased the activity of dentate granule cells and hippocampal pyramidal cells, which were detected using immunocytochemistry for c-Fos and c-Jun proteins (Papa et al., 1993). Furthermore, there was a positive correlation between the area of hippocampal CA3 occupied by axon terminals of dentate granule cells and the speed of habituation in an open field (Crusio and Schwegler, 1987). These results indicate that activity of neural network in the hippocampus, especially in the dentate gyrus where $\mathrm{CB}_{1}$ receptor is strongly expressed, plays important roles in habituation. Consistent with these results, recent studies have 
demonstrated that $\mathrm{CB}_{1}$ knock-out mice habituated to a novel environment faster than wild-type littermates (Degroot et al., 2005). The mechanisms, however, underlying the enhanced habituation of the $\mathrm{CB}_{1}$ knock-out mice are unknown. It remains to be determined which of the two major endocannabinoids, anandamide or 2-arachidonoylglycerol (2-AG), mediates habituation and whether or how synaptic plasticity in the hippocampus is involved. Previous studies have demonstrated that diacylglycerol lipase $\alpha(\mathrm{DGL} \alpha)$ is the major 2-AG synthesizing enzyme in the brain and that 2-AG produced by DGL $\alpha$ mediates retrograde suppression of synaptic transmission (Gao et al., 2010; Tanimura et al., 2010). In contrast, the other 2-AG synthesizing enzyme, DGL $\beta$ 's contribution to 2-AG biosynthesis, is minor in the brain and is dispensable for retrograde synaptic suppression in the brain (Tanimura et al., 2010). Therefore, we used DGL $\alpha$ knockout mice to examine whether 2-AG signaling plays a role in habituation and synaptic plasticity in the hippocampus. The results of the present study suggest that 2-AG-mediated signaling regulates the excitation-inhibition (E-I) balance of the dentate gyrus in favor of inhibition and suppresses long-term potentiation (LTP) at perforant path-granule cell synapses, thereby retarding habituation.

\section{Materials and Methods}

Two- to four-month-old DGL $\alpha$ knock-out mice and wild-type littermates of both sexes were used (Tanimura et al., 2010). In experiments testing the effects of the $\mathrm{CB}_{1}$ antagonist AM251 (Tocris Bioscience) on habituation, 10-week-old male C57BL/6J mice were used. Animals were housed in a plastic cage in a room illuminated with a $12 \mathrm{~h}$ light/dark cycle and fed with standard mouse chow and water ad libitum. All procedures including animal care were approved by the University of Tokyo Animal Care and Use Committee. All behavioral experiments were conducted during the afternoon (13:00-19:00) and the experimenters were blind to animals' genotype.

Odor habituation task. Odor habituation $(\mathrm{OH})$ task was performed as described previously (Guérin et al., 2008). The task was preceded by a period called "shaping" so as to habituate animals to the experimental condition. For shaping, a mouse was placed into a standard Plexiglas mouse cage $(30 \times 19 \mathrm{~cm})$ separated into two equal compartments (X and $\mathrm{Y}$ ) by an opaque, removable wall (see Fig. $1 \mathrm{~A}$ ). The mouse was placed into chamber Y and a cotton swab applied with $60 \mu \mathrm{l}$ of dimethylsulfoxide (DMSO) was placed into chamber X. The intervening wall was then removed and the $50 \mathrm{~s}$ session began. At the end of the session, the mouse was returned into chamber $Y$ for a 5 min intersession interval. After each day's work, mice were returned to their home cages. This shaping process was performed for five subsequent sessions each day, for $3 \mathrm{~d}$.

One day after shaping, mice were subjected to the $\mathrm{OH}$ task. The task was conducted using the same apparatus described above and included five $50 \mathrm{~s}$ sessions with $5 \mathrm{~min}$ intersession intervals. During the first session (pre-odor session), the experimental context was the same as that used for shaping. During the second to fifth sessions (1-4 sessions), $30 \mu \mathrm{l}$ of odorant diluted in $30 \mu \mathrm{l}$ of DMSO was applied to the cotton swab. We used the same odor for the $\mathrm{OH} 1-\mathrm{OH} 4$ sessions. The odor used was a mixture of $25.52 \% 1,8$-cineole, $20.50 \% \alpha$-pinene, 9.33\% camphene, $4.49 \% \beta$-pinene, $17.33 \%$ camphor, and $3.48 \%$ myrcene. During each session, the time that the mouse spent investigating the cotton swab, as was defined by actively sniffing with the nose $<2 \mathrm{~cm}$ away, was measured.

Habituation to open field. DGL $\alpha$ knock-out mice and wild-type littermates were placed into the empty open field $(30 \times 30 \mathrm{~cm})$ and allowed to explore the box for $10 \mathrm{~min}$ once a day for $2 \mathrm{~d}$. To test the effects of the $\mathrm{CB}_{1}$ antagonist AM251 on habituation, C57BL/6J mice injected with AM251 or vehicle were examined in the open field similarly to DGL $\alpha$ knock-out mice but for $3 \mathrm{~d}$. AM251 was dissolved in $0.9 \%$ saline containing $2 \%$ DMSO and $2 \%$ cremophor (Sigma-Aldrich), and was administered intraperitoneally $(20 \mathrm{mg} / \mathrm{kg}$ ) to C57BL/6J mice $30 \mathrm{~min}$ before the start of each session (Xi et al., 2008). The distance traveled was measured every minute using TIME OF4 software (Ohara). Light intensity was adjusted to 10 lux.

Odor-guided transverse patterning task. The task was performed as described previously (Rondi-Reig et al., 2001). Mice were food deprived to maintain $90 \%$ of initial body weight throughout testing. All tests were conducted in a standard $(30 \times 19 \mathrm{~cm})$ clear Plexiglas cage. Odor-guided transverse patterning task was preceded by $5 \mathrm{~d}$ of training. During the training phase, two opaque plastic cups filled with sterilized playground sand were located at the one end of the cage with one of the two cups baited with $20 \mathrm{mg}$ of sucrose pellets. Mice were trained to dig in sandfilled cups based on odor cues to obtain rewards (see Fig. 2A). The odor stimuli were common spices mixed at $0.1 \%$ concentration by weight in sand. The spices used for training were fennel and turmeric while for the transverse task, pepper, paprika, and ginger were used.

In odor-guided transverse patterning task, subjects concurrently solved three overlapping discrimination problems each of which involved a different pairing of odor stimuli described above (Fig. 2B). The odor of pepper was rewarded when presented with the odor of paprika, the odor of paprika was rewarded when presented with the odor of ginger, and the odor of ginger was rewarded when presented with the odor of pepper (Fig. 2B). The task included nine trials per day for 5 consecutive days. On the first day, animals were presented with the odor pairs in an orderly series: pepper and paprika, followed by paprika and ginger, and last ginger and pepper. This order was repeated three times with the location of the baited cup selected at random. The first cup, which animals dug into, was recorded as the first choice in each trial. Mice were allowed to make the correct choice, i.e., digging into the baited cup, on each trial even if they had already made an error. Animals were given a maximum of $10 \mathrm{~min}$ to make the first choice and the cups were removed from the cage once the correct choice was made. If no choice was made within $10 \mathrm{~min}$, a reward was placed on top of the correct cup and the mouse was allowed to retrieve it. During the intertrial interval, the cups were filled with fresh scented sand. The time required for this procedure ranged between 1 and $2 \mathrm{~min}$. The same protocol was used for the following $4 \mathrm{~d}$, except that the odor pairs were presented in a random order. The numbers of successful trials (in which the first choice was correct) were counted on each day. Animals were judged to have achieved the task when they were successful in seven of nine trials. The number of days required to reach this criteria for achievement was compared between DGL $\alpha$ knock-out mice and wild-type littermates.

Electrophysiological experiments in freely moving mice. Implantation of electrodes and the recording of evoked monosynaptic dentate and hippocampal CA1 field EPSP (fEPSP) were performed with minor modifications of previously reported methods in rats (Sugaya et al., 2010). The surgery for the implantation of electrodes was performed on a stereotaxic frame (NARISHIGE) under pentobarbital anesthesia $(50 \mathrm{mg} / \mathrm{kg}$, i.p.). Body temperature was maintained at $37^{\circ} \mathrm{C}$ throughout the surgery with the help of a heating blanket. For the induction of LTP at perforant path-dentate granule cell synapses, stimulation and recording electrodes (polyurethane-coated stainless steel wire with $100 \mu \mathrm{m}$ in diameter) were chronically implanted into the angular bundle $(2.5 \mathrm{~mm}$ lateral, $4.1 \mathrm{~mm}$ posterior to bregma, $1.8 \mathrm{~mm}$ ventral to the dura mater) and the dentate hilus ( $1.1 \mathrm{~mm}$ lateral, $1.9 \mathrm{~mm}$ posterior to bregma, $1.8 \mathrm{~mm}$ ventral to the dura mater), respectively (see Fig. $3 A$ ). For the induction of LTP at Schaffer collateral-CA1 pyramidal cell synapses, stimulation and recording electrodes were chronically implanted into the Schaffer collateral (1.9 $\mathrm{mm}$ lateral, $1.9 \mathrm{~mm}$ posterior to bregma, $1.5 \mathrm{~mm}$ ventral to the dura mater) and the CA1 stratum lacunosum moleculare (1.1 mm lateral, 1.9 $\mathrm{mm}$ posterior to bregma, $1.5 \mathrm{~mm}$ ventral to the dura mater), respectively (see Fig. 5A). Two micro-screws were positioned in the occipital bone as ground and recording indifferent electrodes.

One week after the implantation, evoked local field potentials were recorded in the dentate gyrus (Fig. 3B) or the hippocampal CA1 (Fig. 5B) in freely moving animals. At perforant path-dentate granule cell synapses, half the stimulus current level that could evoke population spikes crossing the baseline voltage level was used to evoke fEPSP. At Schaffer collateral-CA1 pyramidal cell synapses, stimulus intensity was set at half the current level that could evoke maximum fEPSP amplitude. We adopted different criteria for setting the magnitude of the stimulus current 
in the hippocampal CA1 and the dentate gyrus. This is because epileptic seizures were induced in the hippocampal CA1 when the Schaffer collateral was stimulated with the same current as used for stimulation of the perforant path. The perforant path or the Schaffer collateral was stimulated for baseline recordings every $30 \mathrm{~s}$ for $20 \mathrm{~min}$. At perforant pathdentate granule cell synapses, paired-pulse stimulation at interpulse intervals between 20 and $160 \mathrm{~ms}$ with current intensity that could evoke population spikes crossing the baseline voltage level were applied before the baseline recording. The ratio of the second population spike amplitude to the first one was calculated (Adamec et al., 1981). After recording responses to paired-pulse stimuli and baseline fEPSP, theta burst stimulation (TBS) was applied to induce LTP.

TBS consisted of six trains of six bursts of six pulses, with interpulse interval of $2.5 \mathrm{~ms}$, interburst interval of $200 \mathrm{~ms}$, and intertrain interval of $20 \mathrm{~s}$ (Jones et al., 2001), and at the current intensity twice as strong as those used to evoke baseline fEPSP. Following TBS, the perforant path or Schaffer collateral was stimulated every $30 \mathrm{~s}$ at the stimulus intensity used in the baseline recording for a period of $60 \mathrm{~min}$. The amplitudes of evoked fEPSPs before and after TBS were averaged every 2 min and compared between the two genotypes. Signals were amplified (MEG5200; Nihon-Koden) and digitized (PowerLab; AD Instruments) for analysis using MATLAB (MathWorks).

Behavioral experiments after TBS. It is well known that the prior induction of perforant path LTP could interfere with subsequent learning (McNaughton et al., 1986; Barnes et al., 1994). To examine the effect of prior induction of LTP on behavior, we applied TBS to perforant path before odor and spatial habituation tasks. Stimulation and recording electrodes were implanted into the left side of animals' brains. TBS was applied twice with an interstimulus interval of $10 \mathrm{~min}$ to the left perforant path of freely moving DGL $\alpha$ knock-out mice and wild-type littermates in their home cages 1 week after the implantation of the electrodes. Ten minutes after the application of the second TBS, animals were placed in an open field or $\mathrm{OH}$ chamber, and the spatial habituation task or the $\mathrm{OH}$ task was examined as described above. In animals for OH task, the shaping procedures as described above were performed before the day of TBS application.

Electrophysiological experiments in anesthetized mice. Under isoflurane anesthesia (1.5\%), stimulus and recording electrodes were implanted into the angular bundle and the dentate hilus, respectively (Jacob et al., 2012). Stimulation currents were set to evoke a population spike with $40-60 \%$ amplitude of the maximal response and interpulse intervals were varied from 10 to $100 \mathrm{~ms}$ in $10 \mathrm{~ms}$ steps. Paired-pulse ratios with interpulse intervals from 500 to $2000 \mathrm{~ms}$ were not examined because of the lack of significant difference between $\mathrm{CB}_{1}$ knock-out mice and wildtype littermates as described previously (Jacob et al., 2012). The ratio of the second population spike amplitude to the first one was calculated (Adamec et al., 1981).

We also investigated the effect of urethane anesthesia $(1.75 \mathrm{~g} / \mathrm{kg} \mathrm{BW}$, i.p.) on synaptic plasticity in DGL $\alpha$ knock-out mice and wild-type littermates. Methods for the implantation of electrodes and the protocol of stimuli used to induce LTP were the same as described above.

To investigate the strength of synaptic input to the dentate gyrus during odor stimuli, local field potentials were recorded with a 16 channel silicon probe (interelectrode interval of $50 \mu \mathrm{m}$; NeuroNexus Technologies) under urethane anesthesia. Current source density (CSD), which represented the net currents across the membranes of granule cells, was calculated from recorded field potentials. Methods for the implantation of electrodes were the same as described above. After the implantation of electrodes, the stimulus current for evoking population spikes that crossed baseline voltage level was applied into the angular bundle. One dimensional $\operatorname{CSD}(z, t)$, as a function of depth $z$ and time $t$, was calculated by a second-order differencing formula as described previously (Leung et al., 2008); $\operatorname{CSD}(z, t)=\sigma[2 \Phi(z, t)-\Phi(z+\Delta z, t)-\Phi(z-\Delta z, t)] /(\Delta z)^{2}$, where $\Phi(z, t)$ is the potential at depth $z$ and time $t$ and $\Delta z$ is the spacing between adjacent electrodes on the silicon probe (i.e., $50 \mu \mathrm{m}$ ). The conductivity $\sigma$ was assumed to be constant and the CSDs were reported in units of $\mathrm{V} / \mathrm{mm}^{2}$. After determining the silicon probe electrodes that corresponded to the middle and outer molecular layer (see Fig. $7 B$ ), we recorded local field potential during a period of $60 \mathrm{~s}$ (Fig. $7 B$ ). Odor stimuli were applied with the cotton swab from $30 \mathrm{~s}$ after the start of the recording. The cotton swab was held $1 \mathrm{~cm}$ away from the animal's nose, and the odor stimulus was the same as that used in the $\mathrm{OH}$ task. Total sink currents of the middle and outer two-thirds of molecular layer $10 \mathrm{~ms}$ following perforant path stimulation, and those $10 \mathrm{~s}$ before and during odor stimulation, were calculated using MATLAB (MathWorks).

Whole-cell recordings in vivo. Whole-cell recordings from the dentate granule and CA1 pyramidal cells were performed in vivo to investigate their intrinsic membrane properties and the effects of odor stimuli on the membrane potential. Under urethane anesthesia (1.75 g/kg BW, i.p.), animals were mounted on a stereotaxic frame. A craniotomy $(1 \mathrm{~mm}$ diameter) was made over the left hippocampus ( $1.1 \mathrm{~mm}$ lateral, $1.9 \mathrm{~mm}$ posterior to bregma) and the dura was removed. For the implantation of stimulation electrodes, a craniotomy was also made over the angular bundle ( $2.5 \mathrm{~mm}$ lateral, $4.1 \mathrm{~mm}$ posterior to bregma) or the Schaffer collateral (1.9 mm lateral, $1.9 \mathrm{~mm}$ posterior to bregma). The method for the implantation of stimulation electrodes was the same as described above. Patch pipettes were filled with the internal solution containing the following (in $\mathrm{mm}$ ): 135 K-gluconate, 10 HEPES, $10 \mathrm{Na}$ phosphocreatine, $4 \mathrm{KCl}, 4 \mathrm{MgATP}, 0.3 \mathrm{Na} 3 \mathrm{GTP}$, and 5.4 biocytin $(290$ $\mathrm{mOsm}$ ). A pipette with resistance of 6-7 M $\Omega$ for the dentate granule cells and of 5-6 $\mathrm{M} \Omega$ for the CA1 pyramidal cells was mounted on a micromanipulator (NARISHIGE) perpendicular to the surface of the brain. A blind patch method was adopted to obtain whole-cell recordings in the dentate granule cells and CA1 pyramidal cells in vivo (Margrie et al., 2002; Harvey et al., 2009). Positive pressure of 250 mbar was applied while moving the pipette through the cortex. After reaching the depth of 1.8 $\mathrm{mm}$ (for dentate granule cells) or $1.3 \mathrm{~mm}$ (for CA1 pyramidal cells) from the cortical surface, the pressure was reduced to $15 \mathrm{mbar}$ and the pipette was slowly moved down at a speed of $2.5 \mu \mathrm{m} / \mathrm{s}$. A seal test was performed by applying a series of voltage-clamp pulses with amplitude of $10 \mathrm{mV}$. After achieving whole-cell configuration, recordings were made in current-clamp mode with no holding current. The resting membrane potential was determined as the mean membrane potential during a period of $30 \mathrm{~s}$ before applying odor stimulation. After baseline recording, an odor stimulus was applied for $30 \mathrm{~s}$ with the cotton swab that was used in the $\mathrm{OH}$ task, and the changes in membrane potential were recorded. The cotton swab was held $1 \mathrm{~cm}$ away from the animal's nose. In different sets of animals, $500 \mathrm{~ms}$ pulse current with an amplitude of $250 \mathrm{pA}$ or 500 pA was injected into the dentate granule and CA1 pyramidal cells, respectively. The changes in membrane potential and the number of action potentials were then measured. Average membrane potential during 100 ms immediately before the current injection was defined as baseline membrane potential. During current injection, average membrane potential from 15 to $5 \mathrm{~ms}$ before the last action potential was defined as the membrane potential during current injection. The time point when the slope of membrane potential exceeded $50 \mathrm{mV} / \mathrm{ms}$ was defined as that of the initiation of action potential. To investigate the effect of the firing of an action potential on its membrane potential, we examined the changes in membrane potentials of recorded cells before and $200 \mathrm{~ms}$ after perforant path or Schaffer collateral stimuli. After achieving whole-cell configuration in vivo, the perforant path or the Schaffer collateral was stimulated with a $200 \mu$ s pulse. Stimulus intensity was set at $500 \mu \mathrm{A}$. The average membrane potential during $100 \mathrm{~ms}$ before the start of the stimulus was defined as membrane potential before the stimulus. Average membrane potential from 200 to $300 \mathrm{~ms}$ after the stimulus was also determined and the value of membrane potential before the stimulus was subtracted. Data were recorded using a multiclamp700B amplifier (Molecular Devices) and analyzed with AxographX. Twelve hours after the recording, mice were transcardially perfused with $4 \%$ paraformaldehyde (PFA). The brains were removed and stored overnight in $4 \%$ PFA, and then transferred into $20 \%$ sucrose in PBS. The dehydrated blocks were rapidly frozen in dry ice. Brains were cut into coronal sections ( $100 \mu \mathrm{m}$ thick) from 1.4 to $2.5 \mathrm{~mm}$ posterior to bregma serially using a cryostat (Leica Microsystems). Sections were washed in PBS containing $0.5 \%$ Tween 20 for $5 \mathrm{~min}$, then incubated for $2 \mathrm{~h}$ in Alexa Fluor 488 streptavidin (Invitrogen) diluted in PBS (1:1000) to label recorded cells with biocytin.

Statistics. All data are expressed as mean \pm SEM and statistical tests are explained individually for each use. Tukey's test was used for post hoc 
A

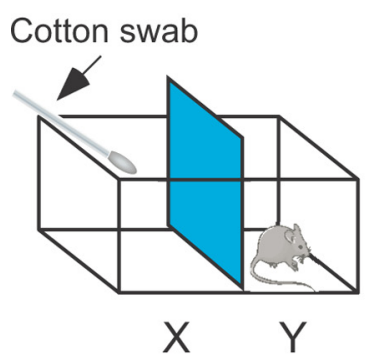

B
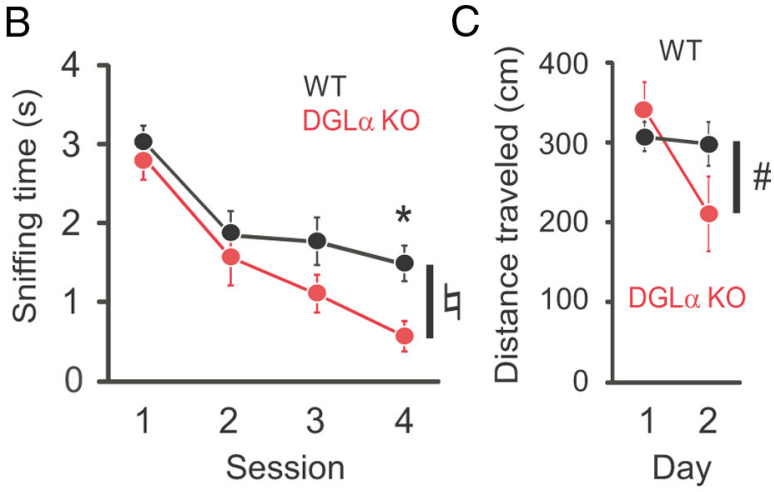

$\mathrm{D}$

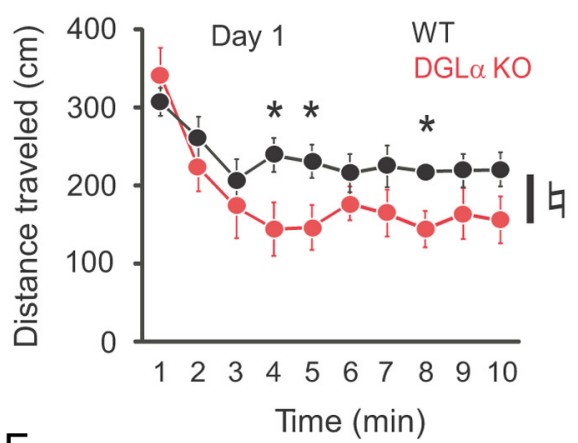

$\mathrm{F}$

$\mathrm{E}$
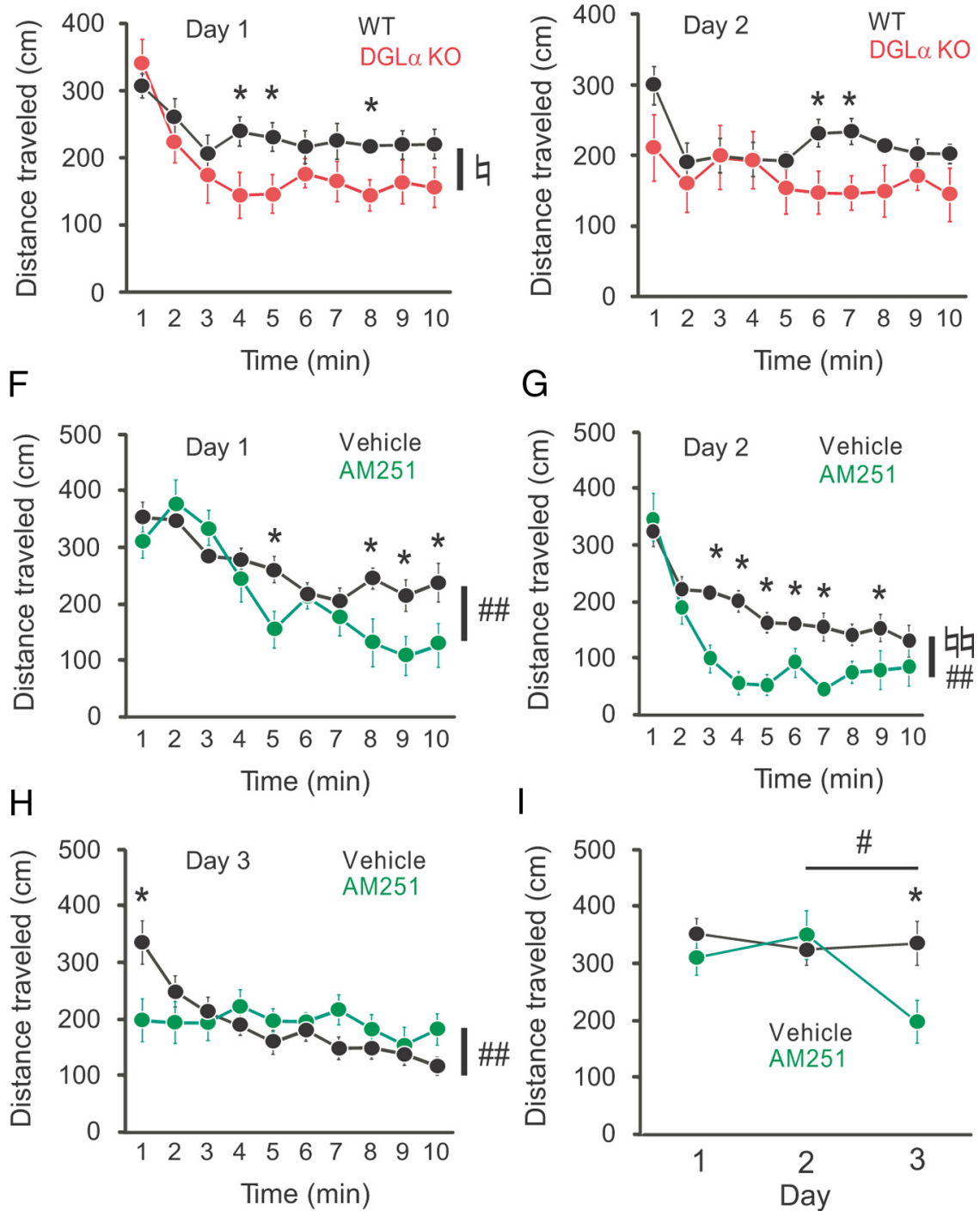

comparison. Differences were regarded as statistically significant when $p<0.05$.

\section{Results}

DGL $\alpha$ knock-out mice exhibit faster habituation than wild-type littermates We first examined the roles of 2-AG signaling in habituation. Repeated exposure to a novel stimulus induces habituation (Leussis and Bolivar, 2006). For odor stimulus, habituation is observed as a gradual decrease in the duration of exploratory behavior to the odorant (Guérin et al., 2008). We repeatedly exposed DGL $\alpha$ knock-out mice and wild-type littermates to an odor stimulus and measured the duration of their exploratory behaviors to the odor stimulus.

Before the $\mathrm{OH}$ task, animals were repeatedly exposed to the experimental apparatus, including a cotton swab without odorant, to habituate them to the experimental environment (see Materials and Methods). On the day of the $\mathrm{OH}$ task, we first examined the exploratory behavior to the experimental environment without odorant (pre-odor session). There was no significant difference between DGL $\alpha$ knock-out mice and wild-type littermates in the duration of exploratory behavior to the cotton swab during pre-odor session $(1.18 \pm 0.42$ and $0.98 \pm 0.28 s$ for DGL $\alpha$ knock-out and wild-type mice, respectively, $t$ test, $t=0.82, p=0.42$ ). We then applied an odorant to the cotton swab and started the $\mathrm{OH}$ task. During the first session of the task, there was no significant difference between the two genotypes in the duration of exploratory behavior to the cotton swab ( $t$ test, $t=0.62, p=0.54$; Fig. $1 B$, Session 1). Thereafter, DGL $\alpha$ knock-out mice and wild-type littermates both showed decrease in the exploratory behavior during the three sessions with an intersession interval of $5 \mathrm{~min}$, indicating that animals of both genotypes habituated to the odorant. However, DGL $\alpha$ knockout mice showed a significant decrease in the duration of exploratory behavior compared with wild-type littermates (two-way ANOVA with repeated measures, $F_{(1,18)}=4.92, p=0.04$ for the effect of genotype, $F_{(3,54)}=0.94, p=0.43$ for the interaction between genotype and session; Fig. $1 B$ ). Post hoc analysis revealed a significant decrease in the duration of exploratory behavior during the fourth session in DGL $\alpha$ knock-out mice when compared with wild-type littermates (Fig. 1B). These results indicate that DGL $\alpha$ knock-out mice showed faster habituation to the odor stimulus compared with wild-type littermates.

Figure 1. Enhanced habituation in $\mathrm{DGL} \alpha$ knock-out (KO) mice and wild-type (WT) mice treated with the $\mathrm{CB}_{1}$ antagonist $\mathrm{AM} 251$. $\boldsymbol{A}$, The $\mathrm{OH}$ chamber consisted of a Plexiglas cage separated into two compartments, $\mathrm{X}$ and $\mathrm{Y}$, by an intervening wall. In $\mathrm{X}$, a cotton swab was arranged as in the schematic. $\boldsymbol{B}$, Changes in sniffing time during four consecutive sessions of the $0 \mathrm{H}$ task in DGL $\alpha$ KO $(n=8)$ and WT $(n=12)$ mice. C, Distance traveled by DGL $\alpha$ KO $(n=10)$ and WT $(n=11)$ mice during the initial minute of the open-field task on the first and second day. $\boldsymbol{D}, \boldsymbol{E}$, Distance traveled by DGL $\alpha$ KO and WT mice during $10 \mathrm{~min}$ in an open field on the first day $(\boldsymbol{D})$ and the second day $(\boldsymbol{E})$. $\boldsymbol{F}-\boldsymbol{H}$, Distance traveled by wild-type mice treated with AM251 $(n=10)$ or vehicle $(n=10)$ during 10 min in an open field on the first day $(\boldsymbol{F})$, the second day $(\boldsymbol{G})$, and the third day $(\boldsymbol{H})$. $\boldsymbol{I}$, Distance traveled by WT mice treated with AM251 or vehicle during the first 1 min of the open field task on the first, second, and third day. Error bars indicate means \pm SEM. $4 p<0.05$ and $\downarrow 4 p<0.01$ for the effect of genotype or treatment in two-way ANOVA. \#p $<0.05$ and \#\# $<0.01$ for the interaction between genotype or treatment and time in two-way ANOVA. ${ }^{*} p<0.05$ in Tukey's test. 
We also examined spatial habituation in DGL $\alpha$ knock-out mice and wild-type littermates in an open field during $10 \mathrm{~min}$ for 2 consecutive days. Normally, locomotor activity of rodents gradually decreases along with habituation in an open field. In the initial minute of the first day, there was no significant difference in the traveled distance between the two genotypes ( $t$ test, $t=0.18$ $p=0.86$; Fig. $1 C$, Day 1). In the successive minutes, DGL $\alpha$ knock-out mice showed a faster decrease in locomotor activity compared with wild-type littermates (two-way ANOVA with repeated measures, $F_{(1,19)}=4.98, p=0.04$ for the effect of genotype, $F_{(9,171)}=1.53, p=0.14$ for the interaction between genotype and time; Fig. 1D). In post hoc analysis, there was a significant decrease in locomotor activity of DGL $\alpha$ knock-out mice in 4, 5, and $8 \mathrm{~min}$ after the exposure to the open field (Fig. $1 D$ ). These results suggest that DGL $\alpha$ knock-out mice habituated to the open field faster than wild-type littermates. Furthermore, DGL $\alpha$ knock-out mice, but not wild-type littermates, showed significantly decreased locomotor activity in the initial minute on the second day compared with that in the initial minute on the first day (two-way ANOVA with repeated measures, $F_{(1,19)}=$ $1.39, p=0.25$ for the effect of genotype, $F_{(1,19)}=5.98, p=0.02$ for the interaction between genotype and day, $p=0.06$ for the post hoc comparison between the two genotypes on the second day; Fig. 1C), also suggesting that DGL $\alpha$ knock-out mice memorized the environment more quickly than wild-type littermates. There was no significant effect of genotype on the traveled distance during $10 \mathrm{~min}$ on the second day (two-way ANOVA with repeated measures, $F_{(1,19)}=2.73, p=0.12$ for the effect of genotype, $F_{(9,171)}=1.71, p=0.09$ for the interaction between genotype and time; Fig. 1E), although we could see a significant decrease in locomotor activity in DGL $\alpha$ knock-out mice 6 and 7 min after the exposure to the open field in Tukey's test. These results indicate that the two genotypes showed similar exploration when fully habituated.

To exclude the possibility that the enhanced habituation of DGL $\alpha$ knock-out mice resulted from the secondary compensatory effects of the lack of 2-AG during neural development, we examined the effects of acute pharmacological blockade of $\mathrm{CB}_{1}$ receptors in wild-type mice. We compared the locomotor activity in the open field between the wild-type mice treated with AM251 30 min before exposure to the open field and those treated with vehicle. On the first day of open-field habituation, AM251treated mice exhibited enhanced habituation (two-way ANOVA with repeated measures, $F_{(1,18)}=1.65, p=0.22$ for the effect of treatment, $F_{(9,162)}=4.03, p<0.001$ for the interaction between treatment and time; Fig. $1 F$ ). Post hoc test revealed a significant decrease in locomotor activity of AM251-treated mice compared with vehicle-treated mice in 5, 8, 9, and 10 min after the exposure to the open field (Fig. 1F). On the second day, the effect on habituation of AM251-treated mice was greater and a significant effect of treatment could be seen (two-way ANOVA with repeated measures, $F_{(1,18)}=14.88, p=0.001$ for the effect of treatment, $F_{(9,162)}=2.66, p=0.007$ for the interaction between treatment and time; Fig. $1 G$ ). In post hoc comparisons, a significant decrease in locomotor activity of AM251-treated mice was observed in 3 to 7 , and 9 min after the exposure to the open field when compared with vehicle-treated mice (Fig. $1 G$ ). On the third day, there was no significant difference in the effect of treatment between the two groups (two-way ANOVA with repeated measures, $F_{(1,18)}=0.06, p=0.81$ for the effect of treatment, $F_{(9,162)}=$ $4.35, p<0.001$ for the interaction between treatment and time; Fig. $1 \mathrm{H}$ ). However, it should be noted that AM251-treated mice showed significantly decreased locomotor activity during the ini-
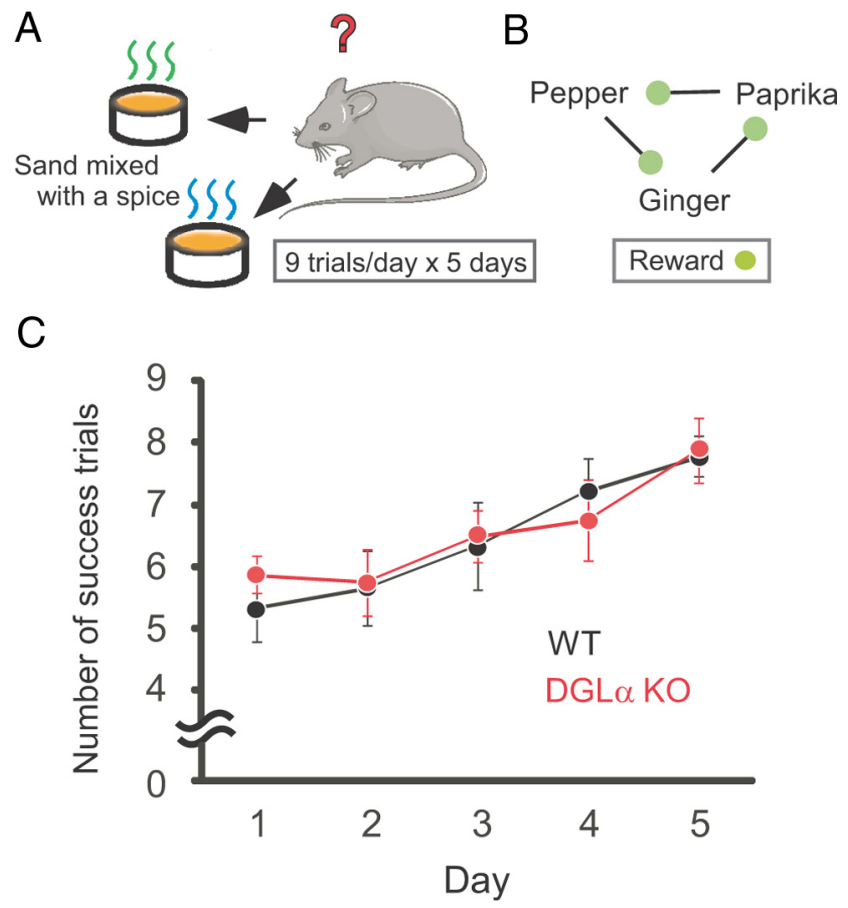

Figure 2. Normal associative learning in the transverse patterning task in DGL $\alpha$ knock-out (KO) mice. A, Schematic of experimental conditions. Two opaque plastic cups were filled with sterilized playground sand. One of the cups was baited with $20 \mathrm{mg}$ of sucrose pellets. Sand in each cup was mixed with a smelling spice and mice dig in sand-filled cups based on odor cues to obtain rewards. A task consisted of nine trials per day for $5 \mathrm{~d}$. $\boldsymbol{B}$, Three overlapping discrimination problems were used in the transverse patterning task. Odor of pepper was rewarded with sucrose pellets when presented with the odor of paprika, odor of paprika was rewarded when presented with odor of ginger, and the odor of ginger was rewarded when presented with the odor of pepper. $\boldsymbol{C}$, Change in the number of successful trials during the transverse odorpatterning task in DGL $\alpha$ KO $(n=8)$ and wild-type (WT) $(n=9)$ mice. Error bars indicate means \pm SEM.

tial minute of the habituation session on the third day when compared with vehicle-treated mice in post hoc analysis (Fig. $1 H)$. Two-way ANOVA with repeated measures also revealed a significant interaction between treatment and day on locomotor activity of the initial minute (two-way ANOVA with repeated measures, $F_{(1,18)}=1.73, p=0.20$ for the effect of treatment, $F_{(1,18)}=7.32, p=0.01$ for the interaction between treatment and day; Fig. 1I). These results suggest that acute blockade of $\mathrm{CB}_{1}$ receptors results in faster habituation to the open field in wildtype mice, and that the enhanced habituation in DGL $\alpha$ knockout mice is the primary consequence of the lack of 2-AG during habituation.

\section{DGL $\alpha$ knock-out mice exhibit normal performance in transverse odor-patterning task}

Next we examined whether 2-AG signaling also contributed to associative learning related to odor information. We used the transverse odor-patterning task, in which the strength of the associative memory depends on hippocampal CA1 region (RondiReig et al., 2001). Performing this test allowed us to compare the contributions of 2-AG signaling to associative learning and to nonassociative learning that are related to the same sensory modality. We defined the level of task achievement as seven successes of nine trials. On the first day of odor-patterning task, there was no significant difference in the number of success trials between the two genotypes (Mann-Whitney $U$ test, $\mathrm{U}=25, p=0.28$, Fig. $2 C$, Day 1). During $5 \mathrm{~d}$ of odor-patterning training, DGL $\alpha$ 
A

B

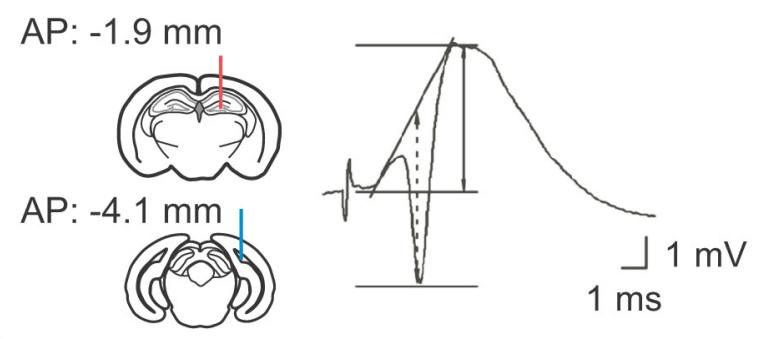

C

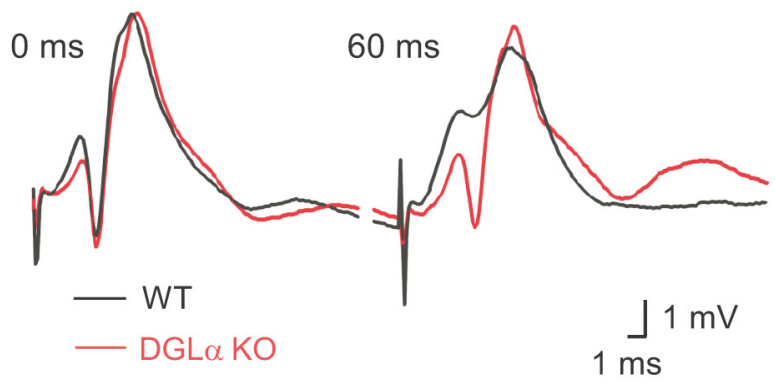

D

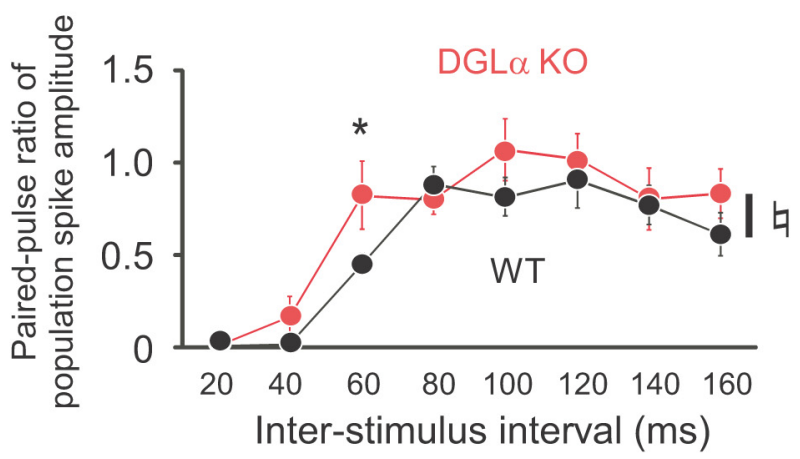

E

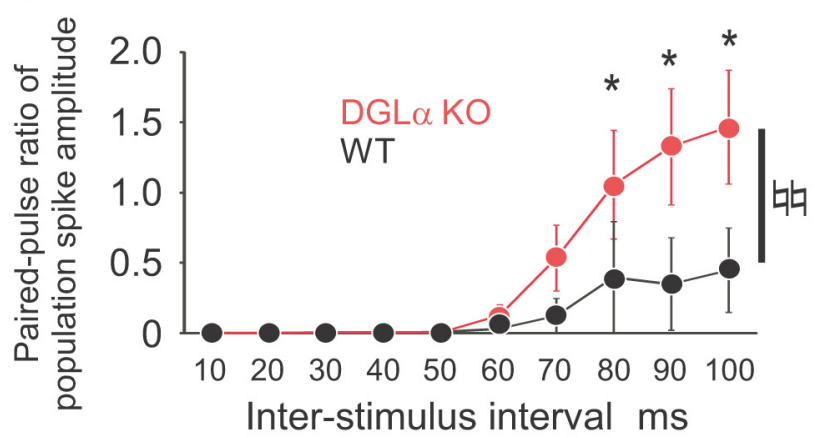

Figure 3. Reduced paired-pulse depression of population spike in freely moving and anesthetized DGL $\alpha$ knock-out (KO) mice. $\boldsymbol{A}$, Schematics diagram showing the positions of recording (top, red line) and stimulation electrodes (bottom, blue line). $\boldsymbol{B}$, An example of the dentate field potentials evoked by medial perforant path stimulation and recorded from one position in the dentate hilus of a wild-type (WT) mouse. The two main components of this potential are the initial positive deflection of the fEPSP and the negative-going population spike. Amplitude of fEPSP is indicated as arrows with solid line, and that of population spike is indicated as arrows with dotted line. C, Sample traces of the dentate field potentials evoked by paired-pulse stimuli with interpulse interval of $60 \mathrm{~ms}$ in a DGL $\alpha$ KO and a WT mouse. $\boldsymbol{D}$, Ratio of population spike amplitude (second spike amplitude/first spike amplitude) evoked by paired-pulse stimuli with interstimulus intervals of $20-160 \mathrm{~ms}$ in DGL $\alpha$ KO $(n=8)$ and WT $(n=8)$ mice. $\boldsymbol{E}$, Ratio of population spike amplitude evoked by paired-pulse stimuli with interstimulus intervals of $10-$ $100 \mathrm{~ms}$ in DGL $\alpha$ KO $(n=5)$ and WT $(n=5)$ mice under isoflurane anesthesia. Error bars indicate means \pm SEM. $\downarrow p<0.05$ and $\downarrow \curvearrowleft p<0.01$ for the effect of genotype in two-way ANOVA. ${ }^{*} p<0.05$ in Tukey's test.
Table 1. Stimulus intensities and fEPSP amplitudes in DGL $\alpha$ knock-out mice and wild-type littermates

\begin{tabular}{|c|c|c|}
\hline & WT & $\mathrm{DGL} \alpha \mathrm{KO}$ \\
\hline \multicolumn{3}{|l|}{ Stimulus intensity } \\
\hline $\begin{array}{l}\text { Perforant path in freely } \\
\text { moving mice }(\mu \mathrm{A})\end{array}$ & $79.44 \pm 22.70(n=9)$ & $67.86 \pm 13.92(n=7)$ \\
\hline $\begin{array}{l}\text { Perforant path in urethane- } \\
\text { anesthetized mice }(\mu A)\end{array}$ & $187.5 \pm 43.85(n=6)$ & $226.7 \pm 37.11(n=5)$ \\
\hline $\begin{array}{l}\text { Schaffer collateral in freely } \\
\text { moving mice }(\mu \mathrm{A})\end{array}$ & $36.67 \pm 6.41(n=6)$ & $37.00 \pm 2.55(n=5)$ \\
\hline \multicolumn{3}{|l|}{ fEPSP amplitude } \\
\hline $\begin{array}{c}\text { Dentate gyrus in freely } \\
\text { moving mice (mV) }\end{array}$ & $1.81 \pm 0.31(n=9)$ & $1.17 \pm 0.35(n=7)$ \\
\hline $\begin{array}{l}\text { Dentate gyrus in urethane- } \\
\text { anesthetized mice (mV) }\end{array}$ & $2.28 \pm 0.47(n=6)$ & $1.92 \pm 0.68(n=5)$ \\
\hline $\begin{array}{l}\text { Hippocampal CA1 in freely } \\
\text { moving mice (mV) }\end{array}$ & $2.58 \pm 0.31(n=6)$ & $3.11 \pm 0.43(n=5)$ \\
\hline
\end{tabular}

knock-out mice and wild-type littermates both showed an increase in the number of successful trials (Fig. $2 C$ ). There was no significant difference, however, in the days required to reach this level between the two genotypes (Mann-Whitney $U$ test, $U=33$, $p=0.76$ ). These results indicate that the lack of $2-A G$ signaling results in enhancement of habituation but does not affect associative learning.

\section{Enhanced LTP in the dentate gyrus of freely moving DGL $\alpha$ knock-out mice}

Hippocampal synaptic plasticity is considered to play important roles in both habituation (Leussis and Bolivar, 2006) and odorpattern learning (Rondi-Reig et al., 2001). For instance, exploration in an open field induces enhancement of synaptic transmission at perforant path-dentate granule cell synapses (Moser et al., 1994). During exploration of a novel environment, LTP in the perforant path-dentate granule cell synapses could be induced by weaker stimuli that did not induce potentiation during the resting state (Sierra-Mercado et al., 2008). These results indicate that LTP at perforant path-dentate granule cell synapses and the enhancement of transmission at these synapses during exploration share common mechanisms. On the other hand, in transverse odor-patterning task, CA1-specific NMDA receptor knock-out mice show impaired pattern learning, indicating that NMDA receptor-dependent LTP in hippocampal CA1 is involved in odor-pattern learning (Rondi-Reig et al., 2001). Based on these previous reports, we hypothesized that altered synaptic plasticity in the dentate gyrus but not in CA1 might result in the faster habituation in DGL $\alpha$ knock-out mice. To test this hypothesis, we examined the synaptic plasticity in the dentate gyrus and CA1 of freely moving DGL $\alpha$ knock-out mice and their wild-type littermates.

The stimulus intensity required to evoke an fEPSP was determined on the basis of the population spike amplitude (Fig. 3B). At perforant path-dentate granule cell synapses, there was no significant difference in the stimulus intensity used to evoke fEPSPs ( $t$ test, $t=0.40, p=0.69$; Table 1 ) or the baseline amplitude of evoked fEPSPs ( $t$ test, $t=1.37, p=0.19$; Table 1 ). However, we found a significant increase in the paired-pulse ratio of the population spike amplitude (two-way ANOVA, $F_{(1,112)}=5.28, p=$ 0.02 for the effect of genotype, $F_{(7,112)}=0.81, p=0.58$ for the interaction between genotype and interpulse interval, and $p=$ 0.03 for the interpulse interval of $60 \mathrm{~ms}$ in post hoc test; Fig. $3 \mathrm{C}, D)$, indicating that DGL $\alpha$ knock-out mice had a shift in E-I 

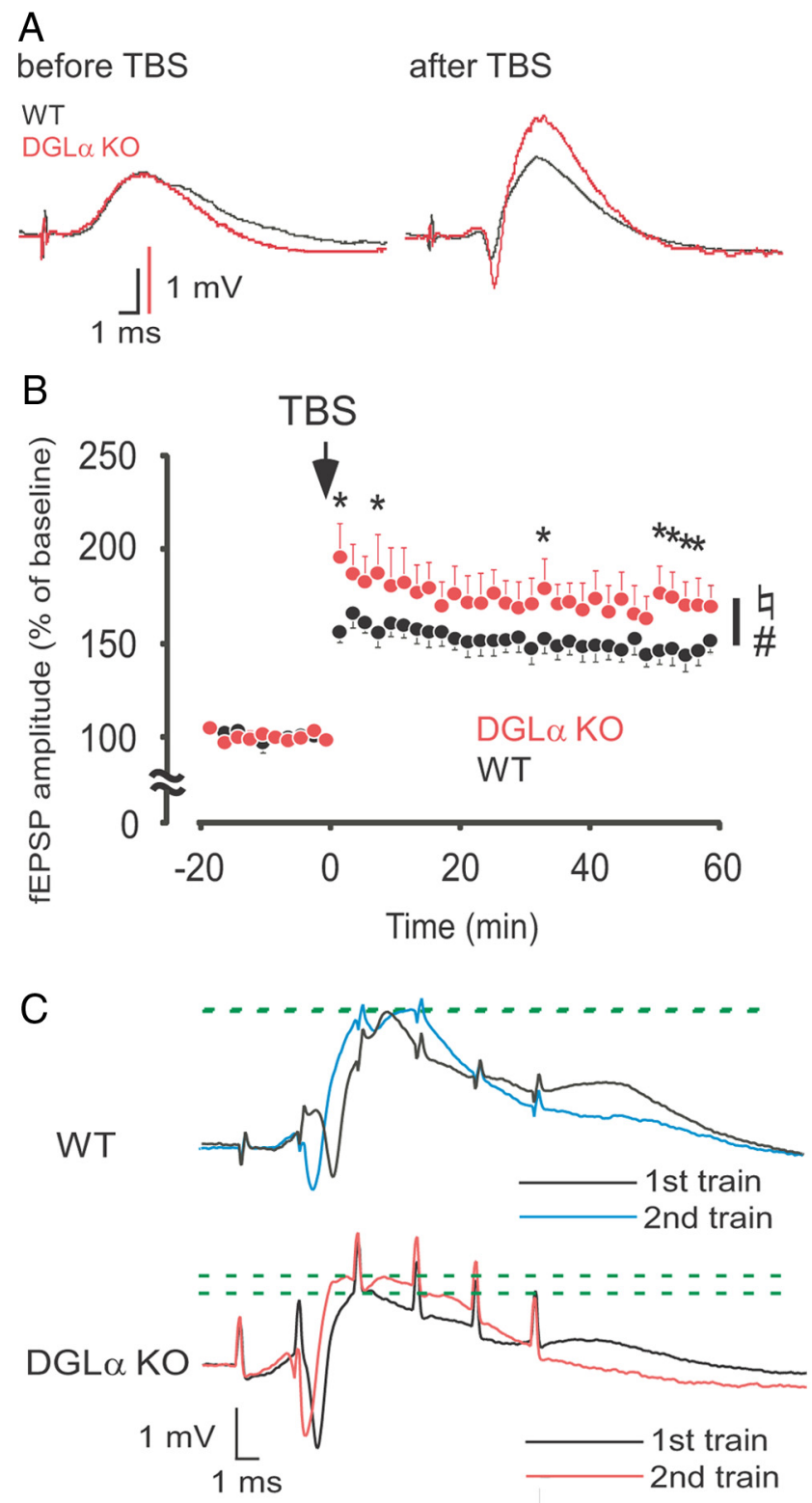

D
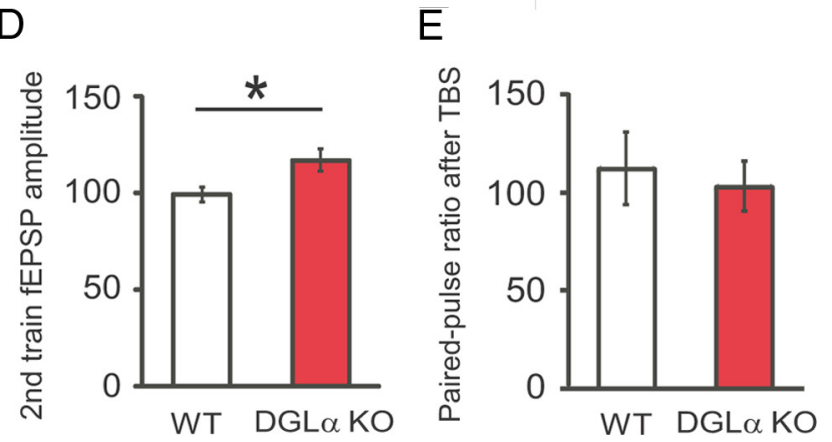

Figure 4. Enhanced LTP and elevated excitability during TBS in freely moving DGL $\alpha$ knockout (KO) mice. $A$, Sample traces of the evoked dentate field potentials before (left) and $60 \mathrm{~min}$ after (right) TBS recorded from a DGL $\alpha$ KO and a wild-type (WT) mouse. Scale bars: $1 \mathrm{mV}, 1 \mathrm{~ms}$. $\boldsymbol{B}$, Time courses of evoked fEPSP amplitude in the dentate gyrus are expressed in percentage of mean fEPSP amplitudes during baseline recording in DGL $\alpha$ KO $(n=7)$ and WT $(n=9)$ mice before and after TBS (arrow). Error bars indicate means \pm SEM. $4 p<0.05$ for the effect of genotype, $\# p<0.05$ for the interaction between genotype and time in two-way ANOVA, and ${ }^{*} p<0.05$ in Tukey's test. $C$, Sample traces of the evoked dentate field potentials during the first six stimuli of the first (black) and second (colored) trains of TBS in a WT (top traces) and a DGL $\alpha$ KO (bottom traces) mouse. Green dotted lines indicate the peak of fEPSP. D, Evoked fEPSP balance to excitation in their synaptic input from the recurrent network in the dentate gyrus.

Opposing results have also recently been reported in $\mathrm{CB}_{1}$ knock-out mice (Jacob et al., 2012). Under isoflurane anesthesia, the paired-pulse ratio of the population spike amplitude in the dentate gyrus was decreased in $\mathrm{CB}_{1}$ knock-out mice when compared with wild-type littermates (Jacob et al., 2012). Therefore, to check the possibility that anesthesia might influence the results, we examined the paired-pulse ratio of the population spike amplitude in DGL $\alpha$ knock-out mice and wild-type littermates under isoflurane anesthesia. As shown in Figure $3 E$, we found a significant increase in the paired-pulse ratio of the population spike amplitude in the dentate gyrus of DGL $\alpha$ knock-out mice compared with wild-type littermates (two-way ANOVA, $F_{(1,80)}=$ $10.98, p=0.001$ for the effect of genotype, $F_{(9,80)}=1.94, p=0.06$ for the interaction between genotype and interpulse interval, Fig. $3 E$ ), which was essentially similar to the results of freely moving mice (Fig. 3). In post hoc test, there was a significant increase in paired-pulse ratio when interpulse interval exceeded $80 \mathrm{~ms}$. These results indicate that the different paired-pulse ratio results should not be ascribed to isoflurane anesthesia but to the different mouse genotypes. Phenotypes of $\mathrm{CB}_{1}$ knock-out mice could differ from those of DGL $\alpha$ knock-out mice because anandamide, another major endocannabinoid, can activate $\mathrm{CB}_{1}$ receptors in DGL $\alpha$ knock-out mice but not in $\mathrm{CB}_{1}$ knock-out mice. Thus, it is possible that anandamide might suppress inhibitory synaptic inputs to dentate granule cells, which might be intact in DGL $\alpha$ knock-out mice but deficient in $\mathrm{CB}_{1}$ knock-out mice, and might cause the difference in the paired-pulse ratio between the two genotypes.

The shift in E-I balance to excitation has been reported to yield strong LTP at perforant path-dentate granule cell synapses in vitro (Arima-Yoshida et al., 2011). Consistent with this result, freely moving DGL $\alpha$ knock-out mice showed significant enhancement of synaptic transmission after TBS compared with wild-type littermates (two-way ANOVA with repeated measures, $F_{(1,14)}=4.98, p=0.04$ for the effect of genotype, $F_{(39,546)}=1.65$, $p=0.01$ for the interaction between genotype and time; Fig. $4 A, B)$. Tukey's test revealed a significant increase in fEPSP amplitude of DGL $\alpha$ knock-out mice compared with wild-type littermates at 2, 8, 34, and 50 to 58 min after TBS. Importantly, when we analyzed the changes in the amplitude of evoked fEPSP during TBS, the amplitude of evoked fEPSP during the second train was significantly larger than that of the first train in DGL $\alpha$ knock-out mice but not in their wild-type littermates ( $t$ test, $t=2.57, p=$ 0.03; Fig. $4 C, D)$. LTP at perforant path-dentate granule cell synapses was reported to occur with presynaptic (Baskys et al., 1991) and postsynaptic mechanisms (Colino and Malenka, 1993). Thus, we also checked the changes in the paired-pulse ratio of the fEPSP $<20 \mathrm{~ms}$ interpulse interval before and after TBS. We found that there was no significant difference between the two genotypes ( $t$ test, $t=0.43, p=0.68$; Fig. $4 E$ ), suggesting that LTP at these synapses is mainly of postsynaptic origin. These results demonstrate that LTP at perforant path-dentate granule cell synapses is significantly enhanced in DGL $\alpha$ knock-out mice when compared with LTP in their wild-type littermates.

$\leftarrow$

amplitude of the first six stimuli of the second train of TBS relative to that of the first train in DGL $\alpha$ KO $(n=7)$ and WT $(n=9)$ mice. $E$, Paired-pulse ratios 60 min after TBS are expressed as percentage of the paired-pulse ratio before TBS in DGL $\alpha$ KO $(n=5)$ and WT $(n=5)$ mice. Error bars indicate means \pm SEM. ${ }^{*} p<0.05, t$ test. 
A

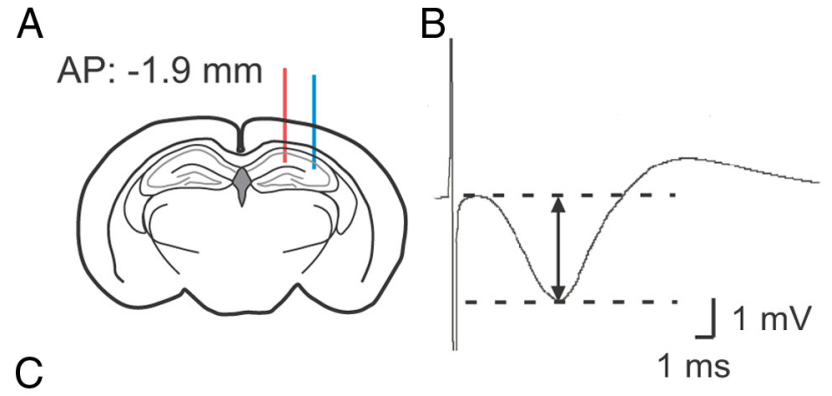

c

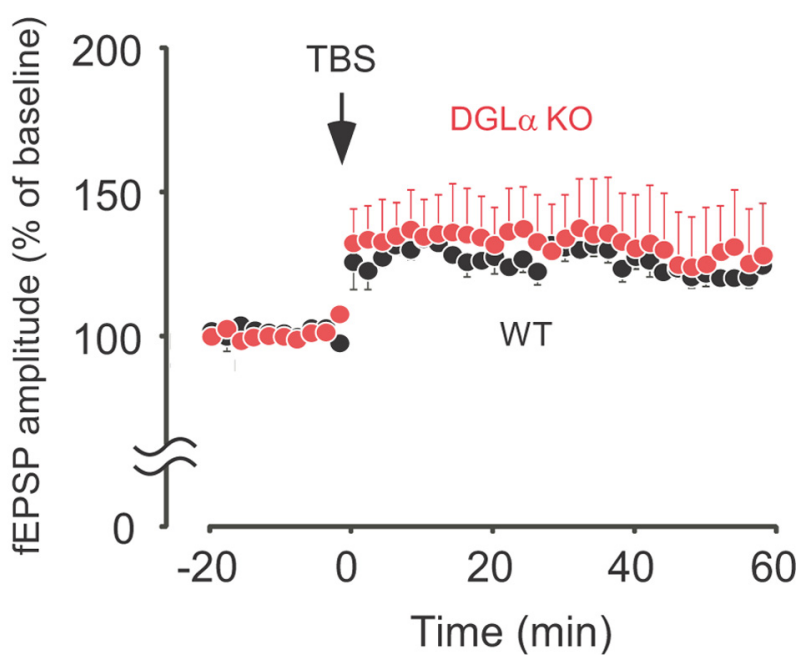

Figure 5. Lack of significant changes in LTP at Schaffer collateral-CA1 pyramidal cell synapses in freely moving DGL $\alpha$ knock-out (KO) mice. $A$, Aschematic diagram showing the positions of recording (red line) and stimulation electrodes (blue line). $\boldsymbol{B}$, Sample trace of the hippocampal CA1 field potentials evoked by Schaffer collateral stimulation and recorded from the CA1 molecular layer of a wildtype (WT) mouse. Amplitude of fEPSP is indicated as arrows with solid line. C, Time courses of evoked fEPSP amplitude in the hippocampal CA1 are expressed in percentage of mean fEPSP amplitudes obtained during baseline recording period (20 $\mathrm{min}$ ) before TBS (arrow) in DGL $\alpha \mathrm{KO}(n=5)$ and WT $(n=6)$ mice. Error bars indicate means \pm SEM.

\section{Lack of significant changes in LTP in the CA1 of freely moving DGL $\alpha$ knock-out mice}

At Schaffer collateral-CA1 pyramidal cell synapses, there was no significant difference between the two genotypes in the stimulus intensity required to evoke fEPSPs ( $t$ test, $t=0.04, p=0.97$; Table 1 ) or in their baseline amplitude ( $t$ test, $t=1.03, p=0.33$; Table 1). After TBS, DGL $\alpha$ knock-out mice did not show significant increase in synaptic potentiation when compared with wild-type littermates (two-way ANOVA with repeated measures, $F_{(1,9)}=0.18, p=0.68$ for the effect of genotype, $F_{(39,351)}=0.31$, $p=0.99$ for the interaction between genotype and time; Fig. $5 C$ ). These results seem to be consistent with the hypothesis that enhanced synaptic plasticity in the dentate gyrus of DGL $\alpha$ knockout mice results in the faster habituation to the novel odor and environment.

Prior induction of LTP in the dentate gyrus retards subsequent habituation in DGL $\alpha$ knock-out mice

It is well known that prior induction of LTP results in the impairment of subsequent learning (McNaughton et al., 1986; Barnes et al., 1994; Moser et al., 1998). Because the increase of fEPSP after TBS was larger in DGL $\alpha$ knock-out mice, prior induction of LTP might influence the behavior of DGL $\alpha$ knock-out mice more significantly than their wild-type littermates. We examined whether the saturation of synaptic plasticity at the dorsal part of the perforant path-dentate granule cell synapses before exposure
A
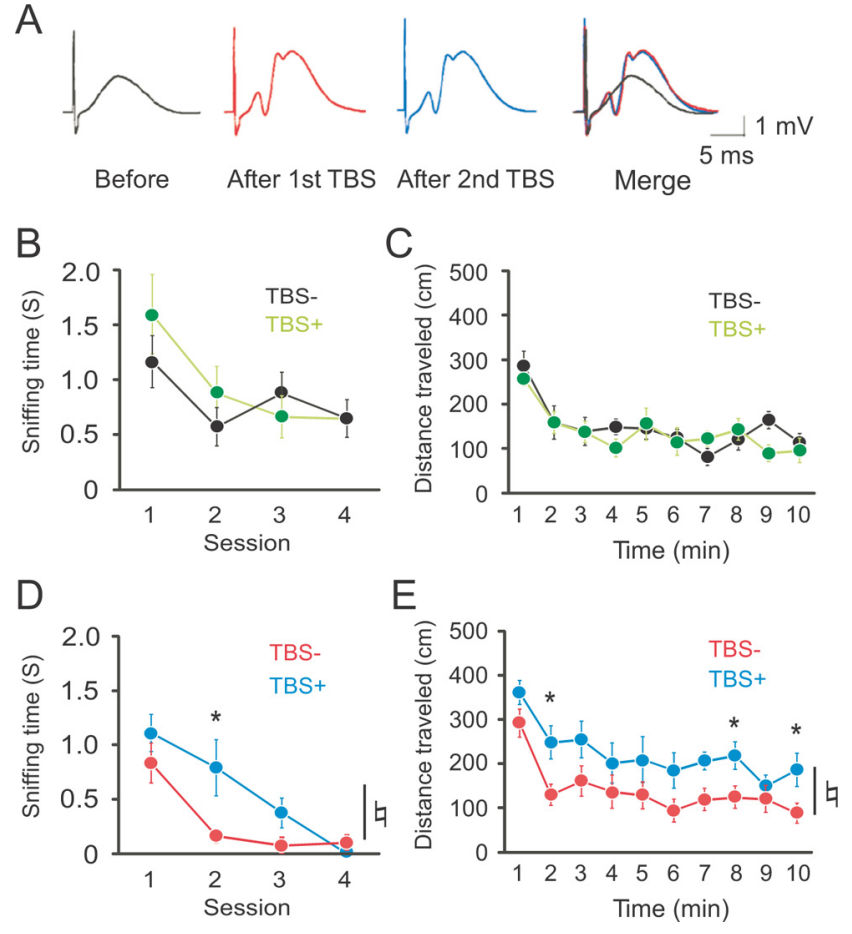

Figure 6. Retarded habituation by preceding induction of synaptic potentiation at perforant path- dentate granule cell synapses in DGL $\alpha$ knock-out but not in wild-type mice. $A$, An example of the changes in dentate field potentials during TBS applied twice with interstimulus interval of $10 \mathrm{~min}$ in a wild-type mouse. $\boldsymbol{B}$, Changes in sniffing time during four consecutive sessions of OH task in wild-type mice with TBS (TBS,$+ n=7$ ) and without TBS (TBS,$- n=7$ ). C, Distance traveled by wild-type mice with TBS $(n=8)$ and without TBS $(n=9)$ during 10 min in an open field. $D$, Changes in sniffing time during four sessions of $0 \mathrm{H}$ task in $D G L \alpha$ knock-out mice with TBS $(n=6)$ and without TBS $(n=7)$. $\boldsymbol{E}$, Distance traveled by DGL $\alpha$ knock-out mice with TBS $(n=7)$ and without TBS $(n=10)$ during $10 \mathrm{~min}$ in an open field. Error bars indicate means \pm SEM. $4 p<0.05$ for the effect of genotype in two-way ANOVA and ${ }^{*} p<0.05$ in Tukey's test.

to the novelty could suppress the enhanced habituation learning observed in DGL $\alpha$ knock-out mice. We applied TBS two times with an interstimulus interval of $10 \mathrm{~min}$ to the perforant path of DGL $\alpha$ knock-out mice and wild-type littermates in their home cages. We confirmed that synaptic potentiation was saturated after one or two trains of TBS in these animals (Fig. 6A).

In wild-type mice, there was no significant difference in the duration of exploratory behavior to the odor stimulus (two-way ANOVA with repeated measures, $F_{(1,12)}=0.37, p=0.55$ for the effect of treatment, $F_{(3,36)}=1.28, p=0.30$ for the interaction between treatment and session; Fig. $6 B$ ) or in the open field between stimulated and nonstimulated groups (two-way ANOVA with repeated measures, $F_{(1,15)}=0.50, p=0.49$ for the effect of treatment, $F_{(9,135)}=0.10, p=0.45$ for the interaction between treatment and time; Fig. $6 C$ ). In contrast, prior induction of synaptic potentiation in DGL $\alpha$ knock-out mice significantly increased the duration of exploratory behavior to the odor stimuli compared with sham-operated DGL $\alpha$ knock-out mice (two-way ANOVA with repeated measures, $F_{(1,11)}=5.79, p=0.03$ for the effect of treatment, $F_{(3,33)}=2.69, p=0.06$ for the interaction between treatment and session; Fig. 6D) without significant effect on the duration of exploratory behavior during the first session $(1.11 \pm 0.18$ and $0.83 \pm 0.17 \mathrm{~s}$ for DGL $\alpha$ knock-out mice with TBS and without TBS, respectively, $t$ test, $t=1.1, p=0.30)$. There was a significant increase in exploratory behavior during second session in DGL $\alpha$ knock-out mice with TBS when compared with 
sham-operated DGL $\alpha$ knock-out mice in post hoc test (Fig. 6D). DGL $\alpha$ knock-out mice with TBS also showed significant increase in the distance traveled in the open field compared with shamoperated DGL $\alpha$ knock-out mice (two-way ANOVA with repeated measures, $F_{(1,15)}=5.70, p=0.03$ for the effect of treatment, $F_{(9,135)}=0.53, p=0.85$ for the interaction between treatment and time; Fig. 6E). Post hoc analysis showed a significant increase of locomotor activity 2, 8, and $10 \mathrm{~min}$ after the exposure to the open field in DGL $\alpha$ knock-out mice with TBS compared with DGL $\alpha$ knock-out mice without TBS (Fig. 6E). There was no significant difference in the distance traveled during the first minute between animals with TBS $(361.10 \pm 27.13$ $\mathrm{cm})$ and without TBS $(292.00 \pm 31.73 \mathrm{~cm})(t$ test, $t=1.55, p=$ $0.14)$. These results suggest that the faster habituation observed in DGL $\alpha$ knock-out mice is attributable to the enhanced LTP at perforant path-dentate granule cell synapses. The 2-AG signaling appears to suppress excessive habituation by inhibiting LTP at perforant path-dentate granule cell synapses.

\section{Normal intrinsic membrane properties of dentate granule cells and CA1 pyramidal cells in DGL $\alpha$ knock-out mice}

To further investigate the mechanisms underlying altered E-I balance and increased synaptic plasticity in the intact neural network of DGL $\alpha$ knock-out mice, we examined the electrophysiological properties of dentate granule cells by in vivo whole-cell recordings under urethane anesthesia $(1.75 \mathrm{mg} / \mathrm{kg})$. We first checked whether LTP at the perforant path-dentate granule cell synapses of DGL $\alpha$ knock-out mice were enhanced, as observed in the freely moving state. There was no significant difference between the two genotypes in the stimulus intensity required to evoke fEPSPs ( $t$ test, $t=0.65, p=0.55$; Table 1 ) or in their baseline amplitude ( $t$ test, $t=0.45, p=0.67$; Table 1 ). After TBS, DGL $\alpha$ knock-out mice showed enhanced synaptic plasticity at perforant path-dentate granule cell synapses under urethane anesthesia (two-way ANOVA with repeated measures, $F_{(1,6)}=$ 17.73, $p=0.006$ for the effect of genotype, $F_{(29,174)}=5.26, p<$ 0.001 for the interaction between genotype and time; Fig. $7 A$ ). In post hoc test, there was a significant increase in fEPSP amplitude throughout the recording after TBS in DGL $\alpha$ knock-out mice compared with wild-type littermates.

Next, we investigated effects of 2-AG on synaptic responses in the dentate gyrus following physiological stimulation. We applied odor stimuli to urethane-anesthetized animals with a cotton swab and recorded local field potentials from the dentate gyrus with a 16 channel silicon probe in DGL $\alpha$ knock-out mice and their wild-type littermates. We then calculated CSD from local field potentials as described previously (Leung et al., 2008). As previously reported, field potentials reflect changes in electrical potential $\sim 250 \mu \mathrm{m}$ (Katzner et al., 2009). Therefore, CSD represents the net membrane current from multiple granule cells within $250 \mu \mathrm{m}$ of the recording electrodes. Negative values in CSD indicate current sink, i.e., net inward current to granule cells around the recording electrode. We first stimulated the perforant path, calculated CSD, and determined the electrodes corresponding to the location of the outer two-thirds of the molecular layer. There was no significant difference in total sink current around the outer two-thirds of the molecular layer ( $t$ test, $t=1.28, p=$ 0.23 ; Fig. $7 B, C$ ). Then, we calculated the total sink current during $10 \mathrm{~s}$ before and during odor stimulus. We found that there was no significant difference in the total sink current between the two genotypes before and during odor stimulus (two-way ANOVA with repeated measures, $F_{(1,10)}=0.01, p=0.91$ for the effect of genotype, $F_{(1,10)}=0.02, p=0.90$ for the interaction between
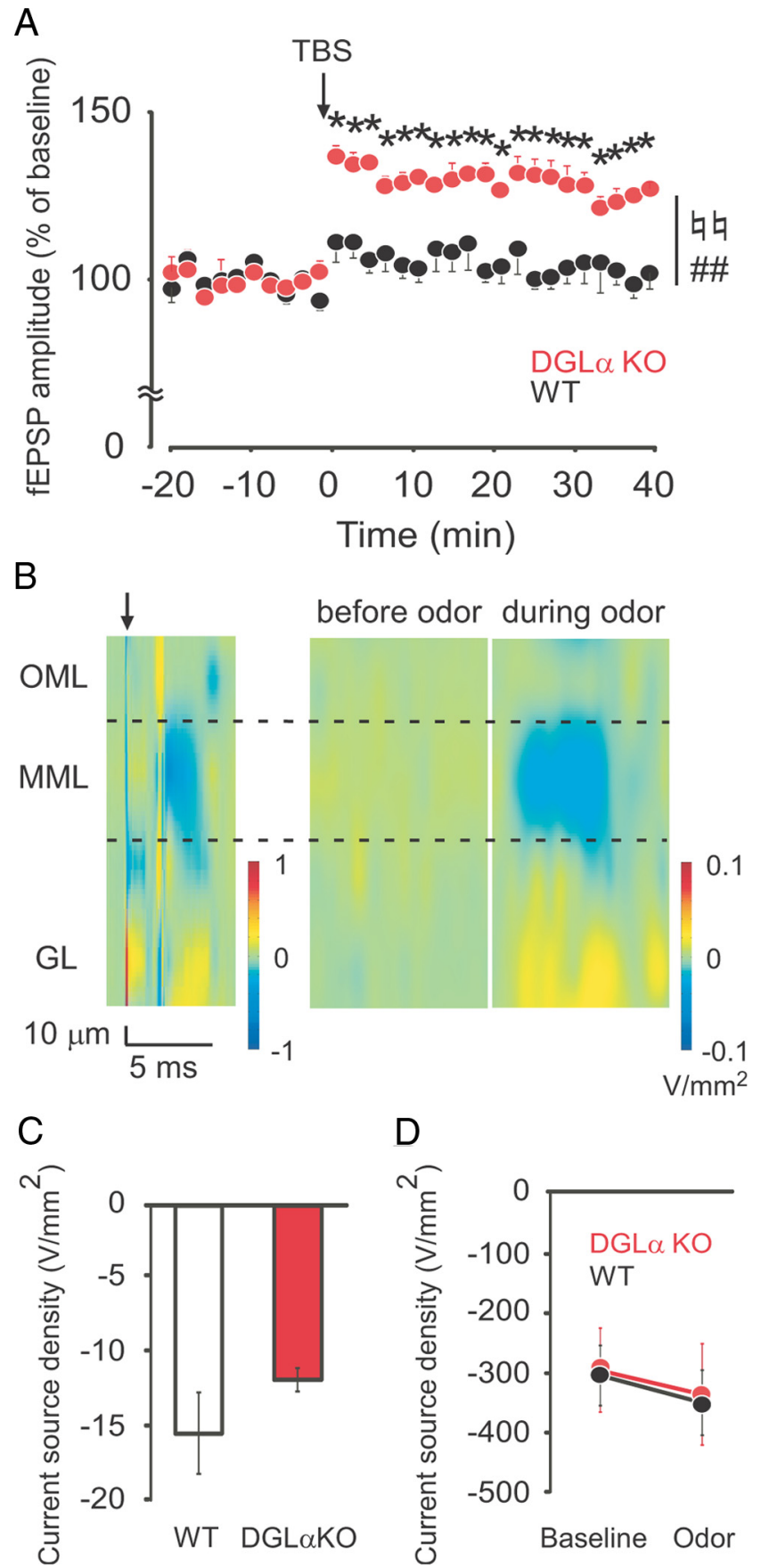

Figure 7. Enhanced LTP but unchanged odor-induced synaptic inputs to the dentate gyrus in DGL $\alpha$ knock-out (KO) under urethane anesthesia. $\boldsymbol{A}$, Time course of fEPSP amplitude in the dentate gyrus in DGL $\alpha$ KO $(n=5)$ and wild-type (WT) $(n=6)$ mice before and after TBS (arrow). $\boldsymbol{B}$, Color maps showing CSD in the dentate gyrus after perforant path stimuli (left), and before (middle) and during (right) exposure to odor. Outer molecular layer $(0 \mathrm{ML})$, middle molecular layer (MML), and granule cell layer (GL) are separated by dotted lines. The arrow on the left indicates the perforant path stimulation. Current sink (blue) after perforant path stimulation corresponds to inward membrane current of the MML. C, Total sink current of MML and OML during $10 \mathrm{~ms}$ after perforant path stimulation in DGL $\alpha$ KO $(n=6)$ and WT $(n=6)$ mice. $D$, Total sink current of MML and OML during $10 \mathrm{~s}$ before and during odor stimulation in DGL $\alpha$ KO $(n=6)$ and WT $(n=6)$ mice. Error bars indicate means \pm SEM. $\downarrow 4 p<0.01$ for the effect of genotype, \#\#p $<0.01$ for the interaction between genotype and time in two-way ANOVA, and ${ }^{*} p<0.05$ in Tukey's test.

genotype and treatment; Fig. $7 B, D)$. These results suggest that there was no significant difference between the two genotypes in the strength of sensory input to the population of dentate granule cells during the odor stimuli. 

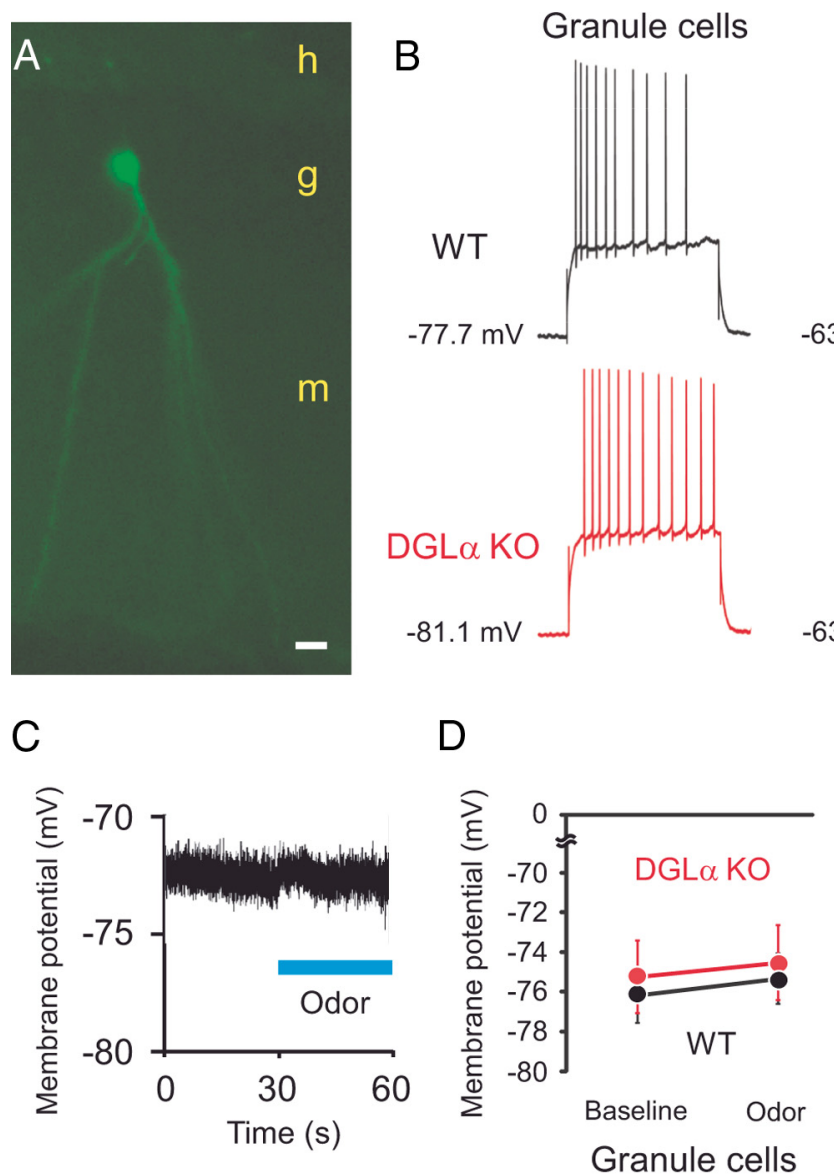

C
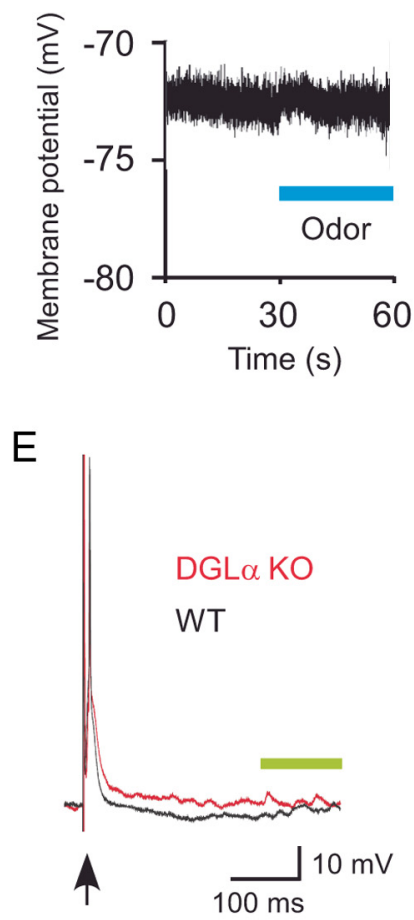

$\mathrm{F}$

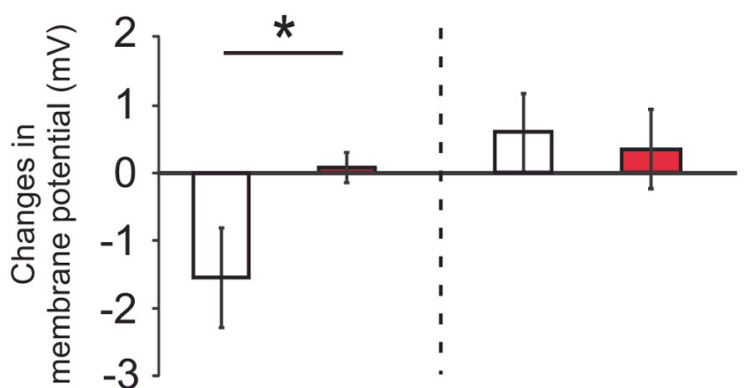

WT DGL $\alpha \mathrm{KO}$

WT DGL $\alpha$ KO

Granule cells

Figure 8. In vivo whole-cell recordings from dentate granule cells and CA1 pyramidal cells of DGL $\alpha$ knock-out (KO) and wild-type (WT) mice during current injection, odor stimulus, and stimulation of excitatory inputs. $A$, A patched granule cell in the dentate gyrus was visualized using immunofluorescent staining for biocytin. $h$, Hilus; $g$, granule cell layer; $m$, molecular layer of the dentate gyrus. Scale bar, $10 \mu \mathrm{m}$. B, Left, Representative traces of membrane potential during $250 \mathrm{pA}$ of current injection for 500 ms in a dentate granule cell of a WT (top) and of a DGL $\alpha$ KO (bottom) mouse. Right, Representative traces of membrane potential during $500 \mathrm{pA}$ of current injection for $500 \mathrm{~ms}$ in a CA1 pyramidal cell of a WT (top) and of a DGL $\alpha$ KO (bottom) mouse. C, Sample trace showing membrane potential of a WT dentate granule cell during odor stimulus. $\boldsymbol{D}$, Left, Membrane potentials of dentate granule cells for 20 s before and during odor stimuli in DGL $\alpha$ KO ( 8 cells from 3 animals) and WT ( 7 cells from 3 animals) mice. Right, Membrane potentials of CA1 pyramidal cells for 20 s before and during odor stimuli in DGL $\alpha$ KO ( 6 cells from 3 animals) and WT ( 5 cells from 3 animals) mice. $E$, Representative traces showing membrane potential in the dentate granule cells of a WT and a DGL $\alpha$ $\mathrm{KO}$ mouse. The arrow indicates the moment of perforant path stimulation. The green bar represents the period from which membrane potentials of dentate granule cells were determined. Error bars indicate means \pm SEM. $\boldsymbol{F}$, Left of the dotted line, Changes in the membrane potentials of dentate granule cells after perforant path stimulation compared with those before the stimulation in WT (7 cells from 3 animals) and DGL $\alpha$ KO (8 cells from 3 animals) mice. Right of the dotted line, Changes in the membrane potentials of CA1 pyramidal cells after Schaffer collateral stimulation compared with those before the stimulus in WT (5 cells from 3 animals) and DGL $\alpha$ KO (5 cells from 3 animals) mice. Error bars indicate means \pm SEM. ${ }^{*} p<0.05$ in $t$ test.

We then used a "blind patch" method to obtain whole-cell recordings from dentate granule cells of anesthetized DGL $\alpha$ knock-out mice and their wild-type littermates (Fig. 8A). There were no significant differences between the two genotypes in the resting membrane potentials, membrane capacitances, and input resistances ( $t$ test, $t=0.41, p=0.69$ for the resting membrane potentials, $t=0.41, p=0.69$ for the membrane capacitances, and $t=$ $0.33, p=0.74$ for the input resistances; Table 2). During the injection of $500 \mathrm{~ms}$ pulse current with amplitude of $250 \mathrm{pA}$ to the dentate granule cells (Fig. 8B), there was no significant difference in the membrane potential and the number of action potentials between the two genotypes $(t$ test, $t=1.37, p=0.19$ for the membrane potential, $t=0.08, p=0.93$ for the number of action potentials; Table 2). These results indicate that there are no significant differences in intrinsic membrane properties of dentate granule cells between the two genotypes in vivo. Therefore, the increased synaptic plasticity at perforant path-dentate granule cell synapses is considered to result from the differences in synaptic inputs to granule cells during TBS. To assess sensory inputs, we introduced odor stimuli to the anesthetized animals and measured the changes in membrane potentials. Odor stimuli immediately induced depolarization of membrane potentials in dentate granule cells of DGL $\alpha$ knock-out mice and their wild-type littermates (Fig. 8C). During odor stimulation, no significant difference was observed between the two genotypes in the membrane potentials of dentate granule cells ( $t$ test, $t=0.34, p=$ 0.74 ; Fig. $8 D$ ) and no action potential discharge were observed in either group of mice. These findings are consistent with those from CSD analysis showing the same level of synaptic input in granule cell population during odor stimulus in the two genotypes. These results demonstrate that there is no significant difference between the two genotypes in the strength of sensory input to the dentate granule cells during odor stimulus under anesthesia.

We also examined the intrinsic membrane properties of CA1 pyramidal cells in DGL $\alpha$ knock-out mice and wild-type littermates. There were no significant differences between the two genotypes in the resting membrane potentials, membrane capacitances, and input resistances ( $t$ test, $t=0.85, p=0.41$ for the resting membrane potentials, $t=0.18, p=0.86$ for the membrane capacitances, and $t=1.27, p=$ 0.22 for the input resistances; Table 3 ). 


\begin{tabular}{|c|c|c|}
\hline & WT & $\mathrm{DGL} \alpha \mathrm{KO}$ \\
\hline $\begin{array}{l}\text { Resting membrane } \\
\text { potential }(\mathrm{mV})\end{array}$ & $-76.8 \pm 1.1(n=11,3$ mice $)$ & $-77.7 \pm 1.9(n=10,5$ mice $)$ \\
\hline Input resistance (M $\Omega$ ) & $147.1 \pm 10.0(n=11,3$ mice $)$ & $142.3 \pm 10.4$ ( $n=10,5$ mice $)$ \\
\hline $\begin{array}{l}\text { Membrane capacitance } \\
\text { (pF) }\end{array}$ & $4.7 \pm 0.3(n=11,3$ mice $)$ & $4.9 \pm 0.3$ ( $n=10,5$ mice $)$ \\
\hline $\begin{array}{l}\text { Membrane potential } \\
\text { during current } \\
\text { injection }(\mathrm{mV})\end{array}$ & $-25.3 \pm 1.6(n=12,4$ mice $)$ & $-28.1 \pm 1.3(n=13,3$ mice $)$ \\
\hline $\begin{array}{l}\text { Number of action } \\
\text { potentials during } \\
\text { current injection }\end{array}$ & $13.9 \pm 2.5(n=12,4$ mice $)$ & $14.7 \pm 2.0(n=13,3$ mice $)$ \\
\hline
\end{tabular}

For each parameter, data were expressed as means \pm SEM. K0, knock-out; WT, wild type.

Table 3. Membrane properties of CA1 pyramidal cells in DGL $\alpha$ knock-out mice and wild-type littermates

\begin{tabular}{|c|c|c|}
\hline & WT & $\mathrm{DGL} \alpha \mathrm{KO}$ \\
\hline $\begin{array}{l}\text { Resting membrane } \\
\text { potential }(\mathrm{mV})\end{array}$ & $-67.0 \pm 1.2(n=8,4$ mice $)$ & $-65.5 \pm 1.4(n=8,4$ mice $)$ \\
\hline Input resistance (M $\Omega$ ) & $84.0 \pm 4.3(n=10,4$ mice $)$ & $76.3 \pm 4.1$ ( $n=8,4$ mice $)$ \\
\hline $\begin{array}{l}\text { Membrane capacitance } \\
\quad(\mathrm{pF})\end{array}$ & $124.1 \pm 8.8(n=10,4$ mice $)$ & $121.4 \pm 12.3(n=8,4$ mice $)$ \\
\hline $\begin{array}{l}\text { Membrane potential } \\
\text { during current } \\
\text { injection }(\mathrm{mV})\end{array}$ & $-25.5 \pm 1.1$ ( $n=6,4$ mice $)$ & $-28.9 \pm 2.0(n=6,4$ mice $)$ \\
\hline $\begin{array}{l}\text { Number of action } \\
\text { potentials during } \\
\text { current injection }\end{array}$ & $15.3 \pm 3.3$ ( $n=6,4$ mice $)$ & $15.7 \pm 2.5$ ( $n=6,4$ mice $)$ \\
\hline
\end{tabular}

For each parameter, data were expressed as means \pm SEM. KO, knock-out; WT, wild type.

During the injection of $500 \mathrm{~ms}$ pulse current with amplitude of 500 pA (Fig. 8B), there was no significant difference in the membrane potential and the number of action potentials between the two genotypes ( $t$ test, $t=1.51, p=0.16$ for the membrane potential, $t=0.08, p=0.94$ for the number of action potentials; Table 3). These results indicate that there are no significant differences between the two genotypes in intrinsic membrane properties of CA1 pyramidal cells in vivo. During odor stimulation, no significant difference was observed between the two genotypes in the membrane potentials of CA1 pyramidal cells (two-way ANOVA with repeated measures, $F_{(1,9)}=0.76, p=0.40$ for the effect of genotype, $F_{(1,9)}=0.02, p=0.76$ for the interaction between genotype and treatment; Fig. $8 D$ ). No action potentials were observed in both mice during the odor stimulation. These results demonstrate that there is no significant difference between the two genotypes in the strength of sensory input to CA1 pyramidal cells during odor stimuli under anesthesia.

Increased excitability of dentate granule cells of DGL $\alpha$ knockout mice after action potential generation

Since we did not observe action potential discharge from recorded dentate granule cells by odor stimuli under anesthesia, the recurrent network in the dentate gyrus should not be activated. However, results from the paired-pulse analysis of the population spike in freely moving mice clearly demonstrate the shift in E-I balance of activated recurrent network to excitation in DGL $\alpha$ knock-out mice (Fig. 3C,D). Furthermore, in the freely moving state, a part of dentate granule cells have been reported to fire intensely (Henze et al., 2002) and should activate recurrent excitatory and inhibitory networks. Therefore, we hypothesized that the increased excitability in the dentate granule cells of DGL $\alpha$ knock-out mice could be induced through action potential discharge of dentate granule cells. We investigated how granule cell firing affected the excitability of dentate granule cells in vivo, in which the neural network of recurrent input was intact. We applied single-pulse stimulation (amplitude, $500 \mu \mathrm{A}$; duration, 200 $\mu s)$ to the perforant path, evoked single action potentials in the dentate granule cells, and compared their membrane potentials before and after the stimulus (Fig. $8 E$ ). We analyzed the membrane potentials of granule cells $200 \mathrm{~ms}$ after the stimulus because TBS used to evoke LTP was applied with a $200 \mathrm{~ms}$ interburst interval. The mean values of membrane potential before the stimulus were $-73.1 \pm 0.92 \mathrm{mV}$ and $-73.52 \pm 0.63 \mathrm{mV}$ for wild-type and DGL $\alpha$ knock-out mice, respectively ( $n=7$ for wild-type; $n=$ 8 for DGL $\alpha$ knock-out mice, $t$ test, $t=0.38, p=0.70)$. The membrane potentials measured $200 \mathrm{~ms}$ after the stimulation were hyperpolarized by $1.55 \pm 0.74 \mathrm{mV}$ in wild-type mice but exhibited almost no change $(0.09 \pm 0.22 \mathrm{mV})$ in DGL $\alpha$ knockout mice ( $t$ test, $t=2.24, p=0.04$; Fig. $8 F$ ). These results indicate that 2-AG signaling suppresses excitability of dentate granule cells after they generate action potentials. In marked contrast, in CA1 pyramidal cells, there was no significant difference in the membrane potentials measured $200 \mathrm{~ms}$ after the Schaffer collateral stimulation between DGL $\alpha$ knock-out mice and their wildtype littermates ( $t$ test, $t=0.59, p=0.57$; Fig. $8 F$ ). This result is consistent with the lack of significant difference between the two genotypes in the field potential amplitudes after TBS in the hippocampal CA1.

\section{Discussion}

We have demonstrated that habituation to an odor and a novel environment, but not associative learning related to odor, was enhanced by the lack of 2-AG signaling in mice. Exposure to a novel environment is known to be correlated with increased synaptic transmission at perforant path-dentate granule cell synapses (Castro et al., 1989; Moser et al., 1994) and also with the expression of plasticity-related genes like c-fos in the dentate gyrus and hippocampal CA1 (Papa et al., 1993). To test the possibility that 2-AG signaling modulates synaptic plasticity in the hippocampus and thereby regulates habituation, we examined LTP at perforant path-dentate granule cell synapses and Schaffer collateral-CA1 pyramidal cell synapses in DGL $\alpha$ knock-out mice that lack retrograde $2-A G$ signaling in the brain. We found that LTP was enhanced at perforant path-dentate granule cell synapses but not at Schaffer collateral-CA1 pyramidal cell synapses. We also found that habituation to an odor and a novel environment was significantly retarded in DGL $\alpha$ knock-out mice when maximal potentiation of perforant path-dentate granule cell synapses was induced before the behavioral task. These results support the idea that LTP at perforant path-dentate granule cell synapses underlies habituation, and suggest that retrograde 2-AG signaling negatively regulates habituation by suppressing excess potentiation at these synapses.

We found no significant differences between the two genotypes in intrinsic membrane properties of the dentate granule cells including resting membrane potential, membrane capacitance, input resistance, and the number of action potentials elicited by membrane depolarization (Table 2). There was no significant difference in the membrane potential of dentate granule cells when they did not generate action potentials. However, once granule cells fired, their excitability became significantly higher in DGL $\alpha$ knock-out mice than in wild-type littermates. These results indicate that activation of recurrent neural circuits involving granule cells is required for 2-AG signaling to influence 

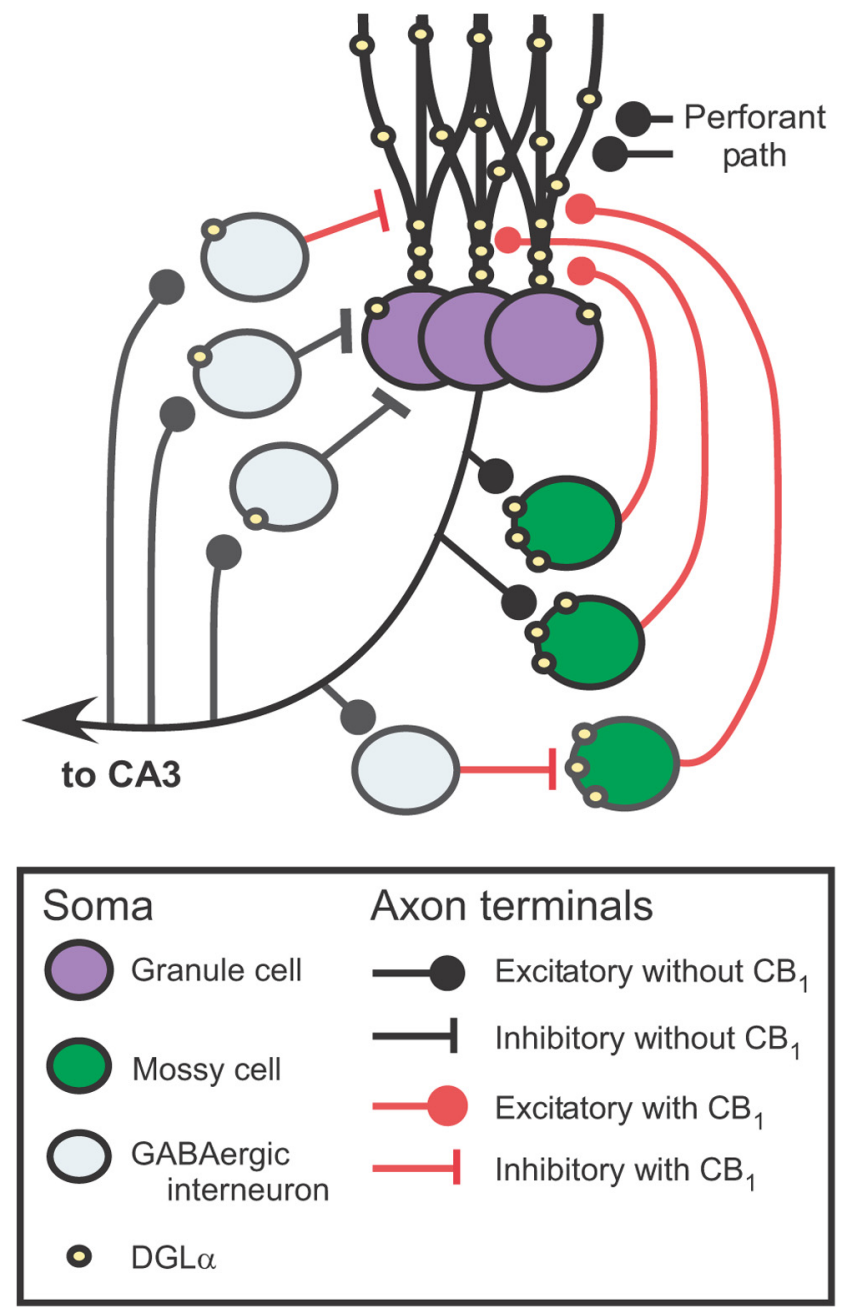

Figure 9. Schema of excitatory and inhibitory recurrent network in the dentate gyrus. In the molecular layer close to the granule cell layer, glutamatergic terminals of mossy cell axons are densely distributed, and most of them express low levels of $\mathrm{CB}_{1}$. The portions of granule cell dendrite in contact with mossy cell terminals express a high level of $D G L \alpha$. In contrast, inhibitory terminals are sparsely distributed, and $30 \%$ of them express high levels of $\mathrm{CB}_{1}$. The portions of granule cell dendrite with which inhibitory terminals are in contact express low levels of $\mathrm{DGL} \alpha$. Therefore, knock-out of $\mathrm{DGL} \alpha$ may result in more selective deletion of retrograde synaptic suppression of recurrent excitatory network than that of $\mathrm{CB}_{1}$ receptor.

granule cell excitability. It is well known that excitatory interneurons called mossy cells exist in the dentate hilus. Mossy cells receive synaptic input mainly from dentate granule cells (Seress, 2007 ) and $\sim 30 \%$ of mossy cells project back to dentate granule cells in the same section with $40-80 \mu \mathrm{m}$ in thickness (Buckmaster et al., 1992). This excitatory recurrent network was suggested to have important roles in learning (Lörincz and Buzsáki, 2000). It should be noted that axon terminals of mossy cells are known to express $\mathrm{CB}_{1}$ receptors (Uchigashima et al., 2011). Global $\mathrm{CB}_{1}$ knock-out mice exhibit severe epileptic seizures by kainic acid injection because of the lack of $\mathrm{CB}_{1}$ receptors presumably in mossy cell terminals (Monory et al., 2006), suggesting that 2-AG signaling suppresses excess excitability of the recurrent network. DGL $\alpha$ is highly accumulated in the neck portion of dentate granule cell spines that are surrounded by $\mathrm{CB}_{1}$ receptor-rich axon terminals of mossy cells (Fig. 9; Uchigashima et al., 2011). In contrast, expression of DGL $\alpha$ in granule cells is very low around input from inhibitory neurons although their axon terminals express $\mathrm{CB}_{1}$ receptors (Uchigashima et al., 2011). These spatial arrangements of DGL $\alpha$ and $\mathrm{CB}_{1}$ suggest that retrograde suppression of excitatory synaptic transmission is more important than that of inhibitory transmission for 2-AG-mediated control of excitability of the recurrent network (Fig. 9). Therefore, it is likely that granule cells produce 2-AG when they generate action potentials during TBS, which suppresses glutamate release from the mossy cell terminals and in so prevents excessive depolarization of the granule cells and counteracting the induction of LTP.

We found no significant difference in the level of synaptic potentiation at Schaffer collateral-CA1 pyramidal cell synapses between DGL $\alpha$ knock-out mice and wild-type littermates. In acute hippocampal slice preparations, several previous studies demonstrated the enhancement of synaptic plasticity by endocannabinoid signaling at Schaffer collateral-CA1 pyramidal cell synapses (Carlson et al., 2002; Chevaleyre and Castillo, 2004; Lin et al., 2011; Pan et al., 2011), whereas other studies showed suppression of synaptic plasticity at the same synapses (Stella et al., 1997; Bohme et al., 2000; Slanina et al., 2005). In anesthetized rats, a $\mathrm{CB}_{1}$ antagonist and agonist both suppressed the synaptic plasticity at Schaffer collateral-CA1 pyramidal cell synapses (Abush and Akirav, 2010). The discrepancies in these results may be attributable to differences in experimental conditions such as preparation, anesthesia, and protocols for inducing synaptic plasticity. For example, LTP measured during whole-cell recordings from CA1 pyramidal cells in hippocampal slices, which is considered to be a more sensitive readout than LTP of population EPSPs (von Engelhardt et al., 2008), was suppressed by blocking $\mathrm{CB}_{1}$ receptors (Carlson et al., 2002; Chevaleyre and Castillo, 2004). In monoacylglycerol lipase knock-out mice with marked elevation of 2-AG, LTP induced by TBS was significantly enhanced, whereas that induced by high-frequency tetanus was unchanged when compared with wild-type mice, at Schaffer collateral-CA1 pyramidal cell synapses (Pan et al., 2011). Thus, further studies with different recording conditions and LTP induction protocols might detect subtle changes in LTP at Schaffer collateral-CA1 pyramidal cell synapses in DGL $\alpha$ knock-out mice.

Habituation is considered to be the most primitive form of nonassociative learning (Leussis and Bolivar, 2006). It was reported previously that $\mathrm{CB}_{1}$ knock-out mice showed excessive habituation (Degroot et al., 2005; Jacob et al., 2009). Furthermore, specific deletion of $\mathrm{CB}_{1}$ receptors in excitatory neurons but not in inhibitory neurons resulted in faster habituation to the dark open field (Jacob et al., 2009). This result indicates that $\mathrm{CB}_{1}$-dependent suppression of glutamatergic transmission leads to retardation of habituation, which is consistent with our present results that 2-AG signaling negatively regulates habituation behavior through the suppression of excitability of granule cells in the dentate gyrus.

In contrast to the present results, previous studies showed that the intraperitoneal injection of a $\mathrm{CB}_{1}$ antagonist, SR141716A, increased locomotor activity (Compton et al., 1996) and also caused suppression of LTP at perforant path-dentate granule cell synapses under isoflurane anesthesia (Sokal et al., 2008). These discrepancies between our results and the previous reports may be attributable to the following reasons. The stimulating effect of SR141716A on locomotor activity may not involve $\mathrm{CB}_{1}$ receptors (Bass et al., 2002) but could result from blockade of TRPV1 receptors (Jin et al., 2004). This argument is consistent with our results showing that AM251, which does not block TRPV1 receptors, reduced locomotor activities during habituation.

In the present study, we induced LTP at perforant path-dentate granule cell synapses before behavioral tasks in both DGL $\alpha$ 
knock-out mice and wild-type littermates. However, the effect of LTP on habituation was observed only in DGL $\alpha$ knock-out mice, which is consistent with the previous report showing the lack of significant effect of LTP on locomotor activity (Wu and Sutherland, 2006). The reasons why the effect was seen only in DGL $\alpha$ knock-out mice remain unclear. However, we found that synaptic potentiation could be induced by a single burst in DGL $\alpha$ knock-out mice but not in wild-type littermates. It is possible that, in DGL $\alpha$ knock-out mice, the full length of TBS would induce LTP at more synapses than in wild-type littermates and cause detectable changes in habituation behavior. Another possibility would be that compensatory neural networks for habituation might be activated more efficiently in wild-type mice than in DGL $\alpha$ knock-out mice. Such a rapid compensation has been reported in the hippocampus. A recent study demonstrated that acute inhibition of the hippocampal neural activity using the fast optogenetic inhibitor eNpHR3.1 resulted in a rapid shift of the required function to other brain regions during memory retrieval task in rats (Goshen et al., 2011). Because habituation behavior is considered to be regulated at multiple levels of the nervous system (Poellinger et al., 2001; Guérin et al., 2008), reduction of learning capacity by the impairment of one mechanism may activate the compensatory mechanisms and maintain the normal speed of habituation seen in wild-type mice.

By using DGL $\alpha$ knock-out mice, we demonstrate evidence that 2-AG signaling is specifically involved in the regulation of LTP and habituation for which the neural circuits in the dentate gyrus are responsible. In contrast to the role of 2-AG signaling in the dentate gyrus, our results suggest that 2-AG signaling may not play important roles in LTP and learning in the CA1. Our results are largely consistent with the previous reports on $\mathrm{CB}_{1}$ knock-out mice (Degroot et al., 2005; Jacob et al., 2009), indicating the major contribution of retrograde $2-\mathrm{AG}$ signaling from postsynaptic neurons to presynaptic $\mathrm{CB}_{1}$ receptors. However, possible contributions of anandamide, the other major endocannabinoid, to synaptic plasticity and learning in the hippocampus are not well understood. Anandamide is reported to exert its action through not only $\mathrm{CB}_{1}$ receptors but also TRPV1 receptors in the dentate gyrus (Chávez et al., 2010). The discrepancy between the present results and those of a recent report on $\mathrm{CB}_{1}$ knock-out mice (Jacob et al., 2012) may suggest a possible contribution of anandamide to the regulation of recurrent inhibition. Careful examinations of DGL $\alpha$ knock-out mice and $\mathrm{CB}_{1}$ knock-out mice and comparison of the phenotypes of these mice will provide information as to relative contribution of 2-AG and anandamide in the regulation of synaptic plasticity and learning in the hippocampus.

\section{References}

Abush H, Akirav I (2010) Cannabinoids modulate hippocampal memory and plasticity. Hippocampus 20:1126-1138. Medline

Adamec RE, McNaughton B, Racine R, Livingston KE (1981) Effects of diazepam on hippocampal excitability in the rat: action in the dentate area. Epilepsia 22:205-215. CrossRef Medline

Arima-Yoshida F, Watabe AM, Manabe T (2011) The mechanisms of the strong inhibitory modulation of long-term potentiation in the rat dentate gyrus. Eur J Neurosci 33:1637-1646.

Barnes CA, Jung MW, McNaughton BL, Korol DL, Andreasson K, Worley PF (1994) LTP saturation and spatial learning disruption: effects of task variables and saturation levels. J Neurosci 14:5793-5806. Medline

Baskys A, Carlen PL, Wojtowicz JM (1991) Long-term potentiation of synaptic responses in the rat dentate gyrus is due to increased quantal content. Neurosci Lett 127:169-172. CrossRef Medline

Bass CE, Griffin G, Grier M, Mahadevan A, Razdan RK, Martin BR (2002) SR-141716A-induced stimulation of locomotor activity. A structure- activity relationship study. Pharmacol Biochem Behav 74:31-40. CrossRef Medline

Bohme GA, Laville M, Ledent C, Parmentier M, Imperato A (2000) Enhanced long-term potentiation in mice lacking cannabinoid $\mathrm{CB}_{1}$ receptors. Neuroscience 95:5-7. Medline

Buckmaster PS, Strowbridge BW, Kunkel DD, Schmiege DL, Schwartzkroin PA (1992) Mossy cell axonal projections to the dentate gyrus molecular layer in the rat hippocampal slice. Hippocampus 2:349-362. CrossRef Medline

Carlson G, Wang Y, Alger BE (2002) Endocannabinoids facilitate the induction of LTP in the hippocampus. Nat Neurosci 5:723-724. Medline

Castillo PE, Younts TJ, Chávez AE, Hashimotodani Y (2012) Endocannabinoid signaling and synaptic function. Neuron 76:70-81. CrossRef Medline

Castro CA, Silbert LH, McNaughton BL, Barnes CA (1989) Recovery of spatial learning deficits after decay of electrically induced synaptic enhancement in the hippocampus. Nature 342:545-548. CrossRef Medline

Chávez AE, Chiu CQ, Castillo PE (2010) TRPV1 activation by endogenous anandamide triggers postsynaptic long-term depression in dentate gyrus. Nat Neurosci 13:1511-1518. CrossRef Medline

Chevaleyre V, Castillo PE (2004) Endocannabinoid-mediated metaplasticity in the hippocampus. Neuron 43:871-881. CrossRef Medline

Colino A, Malenka RC (1993) Mechanisms underlying induction of longterm potentiation in rat medial and lateral perforant paths in vitro. J Neurophysiol 69:1150-1159. Medline

Compton DR, Aceto MD, Lowe J, Martin BR (1996) In vivo characterization of a specific cannabinoid receptor antagonist (SR141716A): inhibition of delta 9-tetrahydrocannabinol-induced responses and apparent agonist activity. J Pharmacol Exp Ther 277:586-594. Medline

Crusio WE, Schwegler H (1987) Hippocampal mossy fiber distribution covaries with open-field habituation in the mouse. Behav Brain Res 26:153158. CrossRef Medline

Degroot A, Salhoff C, Davis RJ, Nomikos GG (2005) Genetic deletion of CB1 receptors improves non-associative learning. Behav Brain Res 162: 161-164. CrossRef Medline

Gao J, Wang WY, Mao YW, Gräff J, Guan JS, Pan L, Mak G, Kim D, Su SC, Tsai LH (2010) A novel pathway regulates memory and plasticity via SIRT1 and miR-134. Nature 466:1105-1109. CrossRef Medline

Goshen I, Brodsky M, Prakash R, Wallace J, Gradinaru V, Ramakrishnan C, Deisseroth K (2011) Dynamics of retrieval strategies for remote memories. Cell 147:678-689. CrossRef Medline

Guérin D, Peace ST, Didier A, Linster C, Cleland TA (2008) Noradrenergic neuromodulation in the olfactory bulb modulates odor habituation and spontaneous discrimination. Behav Neurosci 122:816-826. CrossRef Medline

Harvey CD, Collman F, Dombeck DA, Tank DW (2009) Intracellular dynamics of hippocampal place cells during virtual navigation. Nature 461: 941-946. CrossRef Medline

Henze DA, Wittner L, Buzsaki G (2002) Single granule cells reliably discharge targets in the hippocampal CA3 network in vivo. Nat Neurosci 5:790795. Medline

Jacob W, Yassouridis A, Marsicano G, Monory K, Lutz B, Wotjak CT (2009) Endocannabinoids render exploratory behaviour largely independent of the test aversiveness: role of glutamatergic transmission. Genes Brain Behav 8:685-698. CrossRef Medline

Jacob W, Marsch R, Marsicano G, Lutz B, Wotjak CT (2012) Cannabinoid $\mathrm{CB}_{1}$ receptor deficiency increases contextual fear memory under highly aversive conditions and long-term potentiation in vivo. Neurobiol Learn Mem 98:47-55. CrossRef Medline

Jin K, Xie L, Kim SH, Parmentier-Batteur S, Sun Y, Mao XO, Childs J, Greenberg DA (2004) Defective adult neurogenesis in $\mathrm{CB}_{1}$ cannabinoid receptor knock-out mice. Mol Pharmacol 66:204-208. CrossRef Medline

Jones MW, Errington ML, French PJ, Fine A, Bliss TV, Garel S, Charnay P, Bozon B, Laroche S, Davis S (2001) A requirement for the immediate early gene Zif268 in the expression of late LTP and long-term memories. Nat Neurosci 4:289-296. CrossRef Medline

Kano M, Ohno-Shosaku T, Hashimotodani Y, Uchigashima M, Watanabe M (2009) Endocannabinoid-mediated control of synaptic transmission. Physiol Rev 89:309-380. CrossRef Medline

Katzner S, Nauhaus I, Benucci A, Bonin V, Ringach DL, Carandini M (2009) Local origin of field potentials in visual cortex. Neuron 61:35-41. CrossRef Medline 
Kishimoto Y, Kano M (2006) Endogenous cannabinoid signaling through the $\mathrm{CB}_{1}$ receptor is essential for cerebellum-dependent discrete motor learning. J Neurosci 26:8829-8837. CrossRef Medline

Leung LS, Peloquin P, Canning KJ (2008) Paired-pulse depression of excitatory postsynaptic current sinks in hippocampal CA1 in vivo. Hippocampus 18:1008-1020. CrossRef Medline

Leussis MP, Bolivar VJ (2006) Habituation in rodents: a review of behavior, neurobiology, and genetics. Neurosci Biobehav Rev 30:1045-1064. CrossRef Medline

Lin QS, Yang Q, Liu DD, Sun Z, Dang H, Liang J, Wang YX, Chen J, Li ST (2011) Hippocampal endocannabinoids play an important role in induction of long-term potentiation and regulation of contextual fear memory formation. Brain Res Bull 86:139-145. CrossRef Medline

Lörincz A, Buzsáki G (2000) Two-phase computational model training long-term memories in the entorhinal-hippocampal region. Ann N Y Acad Sci 911:83-111. Medline

Margrie TW, Brecht M, Sakmann B (2002) In vivo, low-resistance, wholecell recordings from neurons in the anaesthetized and awake mammalian brain. Pflugers Arch 444:491-498. CrossRef Medline

Marsicano G, Wotjak CT, Azad SC, Bisogno T, Rammes G, Cascio MG, Hermann H, Tang J, Hofmann C, Zieglgänsberger W, Di Marzo V, Lutz B (2002) The endogenous cannabinoid system controls extinction of aversive memories. Nature 418:530-534. CrossRef Medline

McNaughton BL, Barnes CA, Rao G, Baldwin J, Rasmussen M (1986) Longterm enhancement of hippocampal synaptic transmission and the acquisition of spatial information. J Neurosci 6:563-571. Medline

Monory K, Massa F, Egertová M, Eder M, Blaudzun H, Westenbroek R, Kelsch W, Jacob W, Marsch R, Ekker M, Long J, Rubenstein JL, Goebbels S, Nave KA, During M, Klugmann M, Wölfel B, Dodt HU, Zieglgänsberger W, Wotjak CT, et al. (2006) The endocannabinoid system controls key epileptogenic circuits in the hippocampus. Neuron 51:455-466. CrossRef Medline

Moser EI, Moser MB, Andersen P (1994) Potentiation of dentate synapses initiated by exploratory learning in rats: dissociation from brain temperature, motor activity, and arousal. Learn Mem 1:55-73. Medline

Moser EI, Krobert KA, Moser MB, Morris RG (1998) Impaired spatial learning after saturation of long-term potentiation. Science 281:20382042. CrossRef Medline

Ohno-Shosaku T, Tanimura A, Hashimotodani Y, Kano M (2012) Endocannabinoids and retrograde modulation of synaptic transmission. Neuroscientist 18:119-132. CrossRef Medline

Pan B, Wang W, Zhong P, Blankman JL, Cravatt BF, Liu QS (2011) Alterations of endocannabinoid signaling, synaptic plasticity, learning, and memory in monoacylglycerol lipase knock-out mice. J Neurosci 31: 13420-13430. CrossRef Medline

Papa M, Pellicano MP, Welzl H, Sadile AG (1993) Distributed changes in c-Fos and c-Jun immunoreactivity in the rat brain associated with arousal and habituation to novelty. Brain Res Bull 32:509-515. CrossRef Medline

Poellinger A, Thomas R, Lio P, Lee A, Makris N, Rosen BR, Kwong KK (2001) Activation and habituation in olfaction -an fMRI study. Neuroimage 13:547-560. CrossRef Medline

Robinson L, McKillop-Smith S, Ross NL, Pertwee RG, Hampson RE, Platt B, Riedel G (2008) Hippocampal endocannabinoids inhibit spatial learning and limit spatial memory in rats. Psychopharmacology 198:551-563. CrossRef Medline
Rondi-Reig L, Libbey M, Eichenbaum H, Tonegawa S (2001) CA1-specific $\mathrm{N}$-methyl-D-aspartate receptor knockout mice are deficient in solving a nonspatial transverse patterning task. Proc Natl Acad Sci U S A 98:35433548. CrossRef Medline

Seress L (2007) Comparative anatomy of the hippocampal dentate gyrus in adult and developing rodents, non-human primates and humans. Prog Brain Res 163:23-41. CrossRef Medline

Sierra-Mercado D, Dieguez D Jr, Barea-Rodriguez EJ (2008) Brief novelty exposure facilitates dentate gyrus LTP in aged rats. Hippocampus 18:835843. CrossRef Medline

Slanina KA, Roberto M, Schweitzer P (2005) Endocannabinoids restrict hippocampal long-term potentiation via $\mathrm{CB}_{1}$. Neuropharmacology 49 : 660-668. CrossRef Medline

Sokal DM, Benetti C, Girlanda E, Large CH (2008) The $\mathrm{CB}_{1}$ receptor antagonist, SR141716A, prevents high-frequency stimulation-induced reduction of feedback inhibition in the rat dentate gyrus following perforant path stimulation in vivo. Brain Res 1223:50-58. CrossRef Medline

Stella N, Schweitzer P, Piomelli D (1997) A second endogenous cannabinoid that modulates long-term potentiation. Nature 388:773-778. CrossRef Medline

Sugaya Y, Jinde S, Kato N, Maru E (2010) Levetiracetam inhibits kindlinginduced synaptic potentiation in the dentate gyrus of freely moving rats. Neurosci Res 66:228-231. CrossRef Medline

Tanimura A, Yamazaki M, Hashimotodani Y, Uchigashima M, Kawata S, Abe M, Kita Y, Hashimoto K, Shimizu T, Watanabe M, Sakimura K, Kano M (2010) The endocannabinoid 2-arachidonoylglycerol produced by diacylglycerol lipase $\alpha$ mediates retrograde suppression of synaptic transmission. Neuron 65:320-327. CrossRef Medline

Uchigashima M, Yamazaki M, Yamasaki M, Tanimura A, Sakimura K, Kano M, Watanabe M (2011) Molecular and morphological configuration for 2-arachidonoylglycerol-mediated retrograde signaling at mossy cellgranule cell synapses in the dentate gyrus. J Neurosci 31:7700-7714. CrossRef Medline

Varvel SA, Lichtman AH (2002) Evaluation of $\mathrm{CB}_{1}$ receptor knockout mice in the Morris water maze. J Pharmacol Exp Ther 301:915-924. CrossRef Medline

von Engelhardt J, Doganci B, Jensen V, Hvalby Ø, Göngrich C, Taylor A, Barkus C, Sanderson DJ, Rawlins JN, Seeburg PH, Bannerman DM, Monyer H (2008) Contribution of hippocampal and extrahippocampal NR2B-containing NMDA receptors to performance on spatial learning tasks. Neuron 60:846-860. CrossRef Medline

Wright JW, Murphy ES, Elijah IE, Holtfreter KL, Davis CJ, Olson ML, Muhunthan K, Harding JW (2004) Influence of hippocampectomy on habituation, exploratory behavior, and spatial memory in rats. Brain Res 1023:1-14. CrossRef Medline

Wu Y, Sutherland RJ (2006) Hippocampal evoked potentials in novel environments: a behavioral clamping method. Behav Brain Res 172:63-71. CrossRef Medline

Xi ZX, Spiller K, Pak AC, Gilbert J, Dillon C, Li X, Peng XQ, Gardner EL (2008) Cannabinoid $\mathrm{CB}_{1}$ receptor antagonists attenuate cocaine's rewarding effects: experiments with self-administration and brainstimulation reward in rats. Neuropsychopharmacology 33:1735-1745. CrossRef Medline 